\title{
Does the Endangered Species Act Preempt State Water Law?
}

\section{Robin Kundis Craig*}

\section{INTRODUCTION}

In March 2013, in Aransas Project v. Shaw, ${ }^{1}$ the U.S. District Court for the Southern District of Texas announced, almost in passing, that the Federal Endangered Species Act $(\mathrm{ESA})^{2}$ preempts state water law and the exercise of state water rights. ${ }^{3}$ As a result, the court concluded that the Texas Commission on Environmental Quality had effectuated a "taking" of ESA-listed whooping cranes as a result of state-permitted diversions of fresh water. ${ }^{5}$ This case is currently on review before the U.S. Court of Appeals for the Fifth Circuit, but it raises a question likely to be increasingly important for both aquatic species and water users: When, and to what extent, does the Federal ESA preempt state water law, including the exercise of state-created water rights?

This Article examines that question in much more detail than the Southern District of Texas did. It begins by examining the plethora of water systems in the U.S. that are already subject to ESA controversies as a result, at least in part, of water management decisions and water rights. For a variety of reasons, including both population dynamics and climate change, the number of such systems is increasing, and conflicts between the ESA and state water law are only likely to escalate in the future. In Part III, this Article reviews the basic jurisprudence of federal preemption, outlining the three ways in which federal law can preempt state law-express, implied, and conflict preemption. Finally, Part IV examines how these three types of preemption play out through the ESA.

\footnotetext{
* William H. Leary Professor of Law, University of Utah S.J. Quinney College of Law. My thanks to Jeffrey Mathis, J.D. candidate at the University of Utah College of Law, for his research assistance as my 2013-2014 Quinney Fellow.

1. 930 F. Supp. $2 d 716$ (S.D. Tex. 2013).

2. 16 U.S.C. $\S \S 1531-1544$ (2012).

3. Aransas Project, 930 F. Supp. $2 \mathrm{~d}$ at $745,783-84$.

4. The ESA prohibits takings of listed species through Section 9. 16 U.S.C. $§ 1538$ (2012).

5. Aransas Project, 930 F. Supp. 2d at 786-88.
} 
The Article concludes that the ESA is unlikely to either expressly or implicitly preempt state water law in most circumstances, but that conflict preemption is likely to play an increasingly bigger role in ESAwater law jurisprudence, making Aransas Project $v$. Shaw a harbinger of water rights litigation to come.

\section{FRESH WATER, ESA-LISTED SPECIES, AND THE INCREASING CONFLICTS BETWEEN WATER MANAGEMENT AND THE ESA}

Perhaps surprisingly to some, most waters in the U.S. that are important sources of water supply, including groundwater aquifers, contain ESA-listed species. In general, the connection is immediate and direct: the listed species depend for habitat on the same water humans want to consume-for drinking water, for irrigation, for industrial processes, for energy production, and for waste treatment. ${ }^{6}$ In addition, major water management projects for flood control, water storage, or hydropower can also interfere with species' life cycles and habitats, promoting the ESA's application.

This section begins by providing an overview of the ESA itself, emphasizing how species are listed, what protections listed species receive, and how the ESA has already extensively interacted with freshwater management. It then examines the increasing conflicts between the ESA and water law-first by examining four specific water systems and the conflicts that have arisen between the ESA and individual water rights (the Aransas Project v. Shaw conflict in Texas; the Sacramento-San Joaquin Bay Delta conflicts in California; the Klamath River conflicts in Oregon and California; and the Edwards Aquifer conflicts in Texas), then by providing a more nationwide overview of existing and emerging conflicts between the ESA and water management more generally. As should be clear by the end of this discussion, conflicts between the ESA and water law are both common and increasing, with no simple resolution in sight.

6. See generally David E. Filippi, The Impact of the Endangered Species Act on Water Rights and Water Use, 48 Rocky MTN. MiN. L. INST. 22 (2002) (providing an overview of how state water law can conflict with the ESA). 


\section{A. An Overview of the ESA}

\section{Listing Species for Protection Under Section 4}

Unlike for many environmental statutes, application of the ESA to any particular situation is managerially deliberate, in the sense that the ESA does not apply to any species or any situation until one of two "expert" agencies lists a species for protection using notice-and-comment rulemaking. ${ }^{7}$ The two listing agencies are the U.S. Fish \& Wildlife Service (USFWS), which implements the ESA for terrestrial and freshwater species on behalf of the Secretary of the Interior; and the National Marine Fisheries Service (NMFS), also known as NOAA (National Oceanic and Atmospheric Administration) Fisheries, which implements the ESA for marine and anadromous species on behalf of the Secretary of Commerce. ${ }^{8}$

Section 4 of the ESA governs species listings. ${ }^{9}$ To list a species, the USFWS or NMFS must determine, "solely on the basis of the best scientific and commercial data available to [it] after conducting a review of the status of the species," 10 whether any of five statutory factors exist and are threatening the species under consideration:

(A) the present or threatened destruction, modification, or curtailment of its habitat or range;

(B) overutilization for commercial, recreational, scientific, or educational purposes;

(C) disease or predation;

(D) the inadequacy of existing regulatory mechanisms; or

(E) other natural or manmade factors affecting its continued existence. $^{11}$

If the agency decides to list a species for the ESA's protections, it must also make two other decisions. First, the agency must designate the

7. 16 U.S.C. $\$ 1533(b)(3)(2012)$.

8. See id. $\S \S 1532(15)$ (defining "Secretary" and referencing the Reorganization Plan that divides and assigns these responsibilities), 1533(a) (assigning listing responsibility to the "Secretary").

9. Id. $\S 1533$.

10. Id. $\S 1533(\mathrm{~b})(1)(\mathrm{A})$.

11. Id. $\S 1533(\mathrm{a})(1)(\mathrm{A})-(\mathrm{E})$. 
species as either "endangered" or "threatened." An "endangered species" is "any species which is in danger of extinction throughout all or a significant portion of its range," except for certain insect pests. ${ }^{13}$ A "threatened species," in turn, is "any species which is likely to become an endangered species within the foreseeable future throughout all or a significant portion of its range." 14

Second, at the same time that they list species as endangered or threatened, the USFWS and NMFS are supposed to designate species' critical habitat. ${ }^{15}$ "Critical habitat" is:

(i) the specific areas within the geographical area occupied by the species, at the time it is listed ... . on which are found those physical or biological features (I) essential to the conservation of the species and (II) which may require special management considerations or protection; and

(ii) specific areas outside the geographical area occupied by the species at the time it is listed... , upon a determination by the Secretary that such areas are essential for the conservation of the species. ${ }^{16}$

Critical habitat cannot include "the entire geographical area which can be occupied by the threatened or endangered species"17 or Department of Defense lands subject to a natural resources management plan, ${ }^{18}$ and the listing agency can consider many other factors besides science when designating critical habitat- "the economic impact, the impact on national security, and any other relevant impact...."19 Nevertheless, critical habitat designations must promote the listed species" "conservation," which requires the expert agencies to use "all methods and procedures which are necessary to bring any endangered species or threatened species to the point at which the measures provided pursuant to this chapter are no longer necessary." 20

With respect to the intersection of the ESA and water law, ESAlisted species have a strong aquatic bent. Although the number of species listed is subject to constant revision, the USFWS and NMFS

2. Id. $\S 1533(\mathrm{a})(1),(\mathrm{a})(3)(\mathrm{A})$.

13. Id. $\S 1532(6)$.

14. Id. $\S 1532(20)$.

15. Id. $\S 1533(\mathrm{a})(3)$.

16. Id. $\$ 1532(5)(\mathrm{A})$.

17. Id. $\S 1532(5)(\mathrm{C})$.

18. Id. $\S 1533(\mathrm{a})(3)(\mathrm{B})(\mathrm{i})$.

19. Id. § 1533(b)(2).

20. Id. § 1532(3). 
have listed over 1300 species as of late 2013, which includes species located in foreign countries. ${ }^{21}$ Of the listed species that live within the U.S., 152 are fishes, ${ }^{22} 29$ amphibians, ${ }^{23}$ and 88 clams. $^{24}$ Beyond these categories of species that are inherently directly dependent on water, a number of the 88 species of ESA-listed mammals, 96 species of ESAlisted birds, 46 species of ESA-listed snails, 71 species of ESA-listed insects, 24 species of ESA-listed crustaceans, and 30 species of ESAlisted ferns, ${ }^{25}$ among others, are directly or indirectly dependent on aquatic ecosystems and habitats. Thus, the listing process sets the stage for conflicts between listed species' needs for fresh water and human desires to manage and use that same water.

\section{Section 7 and Federal Agencies' Duties Toward Listed Species}

Once the USFWS or NMFS lists a species under the ESA, the species receives two major sets of legal protections in Section $7^{26}$ and Section $9{ }^{27}$ Section 7 imposes two significant conservation requirements on all federal agencies. First, under Section 7(a)(1), all "Federal agencies shall, in consultation with and with the assistance of the [expert agencies], utilize their authorities in furtherance of the purposes of this chapter by carrying out programs for the conservation of endangered species and threatened species listed" under Section $4 .{ }^{28}$ As noted, this duty to conserve listed species requires federal agencies to use "all methods and procedures which are necessary to bring any endangered species or threatened species to the point at which the

21. Listing Species Under the Endangered Species Act, CTR. FOR BIOLOGICAL DIVERSITY, http://www.biologicaldiversity.org/programs/biodiversity/endangered_species_act/listing_species_u nder_the_endangered_species_act/ (last visited Feb. 23, 2014).

22. Environmental Conservation Online System: Species ad hoc Search: U.S. Fishes, U.S. FISH \& WILDLIFE SERV., http://ecos.fws.gov/tess_public/pub/SpeciesReport.do?groups=E\&listingType= L\&mapstatus=1 (last updated Oct. 28, 2013).

23. Environmental Conservation Online System: Species ad hoc Search: U.S. Amphibians, U.S. FISH \& WILDLIFE SERV., http://ecos.fws.gov/tess_public/pub/SpeciesReport.do?groups=D\&listing Type=L\&mapstatus=1 (last updated Oct. 28, 2013).

24. Environmental Conservation Online System: Species ad hoc Search: U.S. Clams, U.S. FISH \& WILDLIFE SERV., http://ecos.fws.gov/tess_public/pub/SpeciesReport.do?groups=F\&listingType= L\&mapstatus=1 (last updated Oct. 28, 2013).

25. See Endangered Species: U.S. Species, U.S. FISH \& WILDLIFE SERV., http://www.fws.gov/ endangered/species/us-species.html (last updated Oct. 28, 2013) (providing numbers of endangered and threatened species in the U.S.).

26. 16 U.S.C. $\S 1536(2012)$.

27. Id. $\$ 1538$.

28. Id. § 1536(a)(1). 
measures provided pursuant to this chapter are no longer necessary,, 29 including in the water management context.

For example, federal agencies have used Section 7(a)(1) to justify shifting water in federal reclamation projects from human use to the needs of listed species. Thus, when the Secretary of the Interior refused to sell water from the Stampede Dam and Reservoir in Nevada for municipal and industrial use in order to keep additional water in the system to benefit the ESA-listed cui-ui fish and Lahontan cutthroat trout, the U.S. Court of Appeals for the Ninth Circuit upheld that decision under Section 7(a)(1), concluding that the Secretary was not required to sell the water under the authorizing Washoe Project Act and that Section 7(a)(1) gave him independent legal authority to use the water to conserve the fish. ${ }^{30}$

Citizens have also used Section 7(a)(1) to force federal agencies to manage water and other programs for the better benefit of ESA-listed species. ${ }^{31}$ For example, in Sierra Club v. Glickman, ${ }^{32}$ the U.S. Court of Appeals for the Fifth Circuit concluded that the U.S. Department of Agriculture (USDA) had failed to comply with Section 7(a)(1) with respect to the USDA's various crop subsidy programs because: (1) Section 7(a)(1) imposes an affirmative duty on federal agencies to conserve ESA-listed species; ${ }^{33}$ (2) the USDA had never consulted with the USFWS regarding the effects of the USDA's crop subsidy programs on five ESA-listed species ("the fountain darter, the San Marcos gambusia (which may now be extinct), the San Marcos salamander, the Texas blind salamander, and Texas wild rice") ${ }^{34}$ that depend on the Edwards Aquifer in Texas, which the farmers were using as a source of irrigation water; ${ }^{35}$ and (3) the USDA was not using its authorities to conserve these five species. ${ }^{36}$

\footnotetext{
29. Id. § 1532(3).

30. Carson-Truckee Water Conservancy Dist. v. Clark, 741 F.2d 257, 259-63 (9th Cir. 1984).

31. The ESA contains a citizen-suit provision, which allows "any person" to bring suit "to enjoin any person, including the United States and any other governmental instrumentality or agency ... who is alleged to be in violation of any provision of this chapter or any regulation issued under the authority thereof . ..." 16 U.S.C. $§ 1540(\mathrm{~g})(1)(\mathrm{A})$ (2012). In addition, against federal agencies, citizens also often have a cause of action under the Federal Administrative Procedure Act's (APA's) judicial review provisions. See 5 U.S.C. $§ \S 701-706$ (2012) (detailing when suits against federal agencies are allowed).

32. 156 F.3d 606 (5th Cir. 1998).

33. Id. at 616 .

34. Id. at 610 .

35. Id. at 618

36. Id. at 617-18. Cf. Pyramid Lake Paiute Tribe of Indians v. U.S. Dept. of Navy, 898 F.2d
} 
Second, Section 7(a)(2) imposes even more extensive consultation and species protection requirements on federal agencies. Specifically:

Each Federal agency shall, in consultation with and with the assistance of the [expert agencies], insure that any action authorized, funded, or carried out by such agency (hereinafter in this section referred to as an "agency action") is not likely to jeopardize the continued existence of any endangered species or threatened species or result in the destruction or adverse modification of habitat of such species which is determined ... to be critical, unless such agency has been granted an exemption for such action by the Committee pursuant to subsection (h) of this section. In fulfilling the requirements of this paragraph the agency shall use the best scientific and commercial data available.

Under the USFWS's and NMFS's joint regulations for Section 7, to "[j] eopardize the continued existence of means to engage in an action that reasonably would be expected, directly or indirectly, to reduce appreciably the likelihood of both the survival and recovery of a listed species in the wild by reducing the reproduction, numbers, or distribution of that species." ${ }^{38}$ However, as Section 7(a)(2) notes, any federal agency can apply for an exemption from these requirements through the Endangered Species Committee (also known as the "God Squad"), ${ }^{39}$ but the criteria for such exemptions are strict, ${ }^{40}$ few such exemptions have been granted, and the Committee has never allowed a federal agency to drive a species to extinction. ${ }^{41}$

1410, 1417-18 (9th Cir. 1990) (holding that, when the Navy did consult with the USFWS regarding the effects, on ESA-listed fish, of its leasing of acreage and water rights to local farmers, it retained discretion regarding how exactly it would comply with Section 7(a)(1) and did not have to implement the option that was least burdensome to the fish). See also Nat'l Wildlife Fed'n v. Norton, 332 F. Supp. 2d 170, 187-88 (D.D.C. 2004) (concluding that the U.S. Army Corps of Engineers had developed a program to conserve ESA-listed Florida panthers that complied with Section 7(a)(1) in connection with its issuance of a Clean Water Act "dredge and fill" permit for a limestone mine); Protect Our Water v. Flowers, 377 F. Supp. 2d 844, $869-70$ (E.D. Cal. 2004) (concluding that the Army Corps had complied with Section 7(a)(1) with respect to the ESA-listed red-legged frog and kit fox when it issued a dredge and fill permit); Nw. Envtl. Advocates v. EPA, 268 F. Supp. 2d 1255, 1273 (D. Or. 2003) (holding that the U.S. Environmental Protection Agency (EPA) was adequately using its Clean Water Act authorities to comply with Section 7(a)(1) when the EPA was participating in six multispecies water conservation programs to benefit ESA-listed salmon and trout in the Columbia and Willamette Rivers in Oregon).

37. 16 U.S.C. $\$ 1536(\mathrm{a})(2)(2012)$.

38. 50 C.F.R. $§ 402.02(2013)$.

39. See, e.g., Portland Audubon Soc'y v. Endangered Species Comm., 984 F.2d 1534, 1536 (9th Cir. 1993) (stating that the Endangered Species Committee is "known popularly as 'The God Squad"').

40. 16 U.S.C. $\S 1536(\mathrm{~h})(2012)$.

41. Robin Kundis Craig, Environmental Law in Context 350-52 (3d ed. 2012) 
Section 7(a)(2) also imposes procedural requirements on federal agencies. ${ }^{42}$ When a federal agency is contemplating an action, it first engages in informal consultation with the two expert agencies. ${ }^{43}$ The purpose of informal consultation is to figure out whether the agency action might affect ESA-listed species. ${ }^{44}$ As the USFWS explains, "If it appears that the agency's action may affect a listed species, that agency may then prepare a biological assessment to assist in its determination of the project's effect on a species." 45 If one of the expert agencies determines that the proposed agency action is likely to adversely affect ESA-listed species, formal consultation begins. ${ }^{46}$ During formal consultation, the relevant expert agency produces a formal Biological Opinion stating its conclusions as to whether the proposed action will jeopardize any species or damage or destroy its critical habitat, suggesting reasonable and prudent alternatives if necessary to avoid violating Section 7(a)(2), and providing the action agency with an Incidental Take Statement, if necessary, to insulate the action agency from liability under Section $9 .^{47}$

Section 7(a)(2) has been, by far, the most litigated provision of the ESA, and its applicability can significantly affect water management in systems where there are federal dams or reclamation projects or other kinds of federal "handles." 48 Notably, the first major ESA case that the U.S. Supreme Court decided, Tennessee Valley Authority v. Hill, ${ }^{49}$ was a Section 7(a)(2) case involving the Tennessee Valley Authority's (TVA's) construction of the Tellico Dam on the Little Tennessee River. ${ }^{50}$ According to the best science available at the time, completion of the

(describing the amendments that created the Endangered Species Committee and the history of the use of this exemption process).

42. 16 U.S.C. $\S 1536(a)(2)$ (2012).

43. Section 7 Consultation: A Brief Explanation, U.S. FISH \& WILDLIFE SERV., http://www.fws.gov/midwest/endangered/section7/section7.html (last updated Oct. 24, 2012).

44. Id.

45. Id. See also 16 U.S.C. $\S 1536(c)(1)$ (2012) (describing the biological assessment and its role in the consultation process).

46. Section 7 Consultation: A Brief Explanation, U.S. FiSH \& WiLdLIFE SERV., http://www.fws.gov/midwest/endangered/section7/section7.html (last updated Oct. 24, 2012).

47. 16 U.S.C. $\S 1536(b)$ (2012).

48. See James C. Kilbourne, The Endangered Species Act Under the Microscope: A Closeup Look from a Litigator's Perspective, 21 ENVTL. L. 499, 525 (1991) (stating that ESA Section 7(a)(2) is "undoubtedly the most well-known, and certainly the most frequently litigated, obligation pertaining to federal agencies").

49. 437 U.S. 153 (1978).

50. Id. at 157 . 
dam would eradicate the newly ESA-listed snail darter, a small fish. ${ }^{51}$ The Court concluded that, under the plain mandate of Section 7(a)(2), the TVA could not complete the dam. ${ }^{52}$

While Congress later intervened specifically to allow the TVA to finish building Tellico Dam, Section 7(a)(2) remains an important component of legal conflicts between ESA-listed species and water management. ${ }^{53}$ Specifically, and to give some sense of the ESA's influence in this context, Section 7(a)(2) has been instrumental in the evolution of water law-species conflicts in the Androscoggin River in Maine $;{ }^{54}$ Butte Creek in California $;{ }^{55}$ the multi-state Colorado River $;{ }^{56}$ the Columbia River in Oregon, Washington, and Idaho; ${ }^{57}$ the Coosa River in Alabama and Georgia; ${ }^{58}$ the Cowlitz River in Washington; ${ }^{59}$ the Edwards Aquifer in Texas $;{ }^{60}$ the Everglades in Florida $;{ }^{61}$ Icicle Creek in Washington; ${ }^{62}$ Joe's Branch in Alabama; ${ }^{63}$ the Klamath River Basin in

51. Id. at $171-72$.

52. Id. at $193-95$.

53. Robin Kundis Craig, Environmental LaW in Context 348-50 (3d ed. 2012) (describing the fate of the Tellico Dam in the aftermath of the Supreme Court's decision).

54. See generally, e.g., Friends of Merrymeeting Bay v. U.S. Dept. of Commerce, 810 F. Supp. 2d 320 (D. Me. 2011). By design, this list focuses on water use as it is traditionally conceived in water law - that is, the withdrawal of water from a source and its application to some use, with or without return flow, or the physical control of waterways for human purposes. Notably, however, water quality issues and water pollution can also create conflicts with ESA-listed species. See, e.g., Dow AgroSciences LLC v. Nat'1 Marine Fisheries Serv., 707 F.3d 462 (4th Cir. 2013) (evaluating NMFS's recent Biological Opinion concluding that use of certain pesticides near waterways jeopardizes several species of ESA-listed salmonids).

55. See generally, e.g., Cal. Sportfishing Prot. Alliance v. FERC, 472 F.3d 593 (9th Cir. 2006).

56. See generally, e.g., Grand Canyon Trust v. U.S. Bureau of Reclamation, 691 F.3d 1008 (9th Cir. 2012); Grand Canyon Trust v. U.S. Bureau of Reclamation, 623 F. Supp. 2d 1015 (D. Ariz. 2009); Grand Canyon Trust v. U.S. Bureau of Reclamation, No. CV-07-8164 PCT-DGC, 2008 WL 4417227 (D. Ariz. Sept. 26, 2008); Defenders of Wildlife v. Norton, 257 F. Supp. 2d 53 (D.D.C. 2003); Sw. Ctr. for Biological Diversity v. U.S. Bureau of Reclamation, 6 F. Supp. 2 d 1119 (D. Ariz. 1997).

57. See generally, e.g., Nat'1 Wildlife Fed'n v. Nat'l Marine Fisheries Serv., 524 F.3d 917 (9th Cir. 2008); Aluminum Co. of Am. v. Bonneville Power Admin., 175 F.3d 1156 (9th Cir. 1999); Nat'l Wildlife Fed'n v. Nat'l Marine Fisheries Serv., 839 F. Supp. 2d 1117 (D. Or. 2011); Idaho Dept. of Fish \& Game v. Nat'1 Marine Fisheries Serv., 850 F. Supp. 886 (D. Or. 1994).

58. See generally, e.g., Ala. Power Co. v. FERC, 979 F.2d 1561 (D.C. Cir. 1992).

59. See generally, e.g., Cowlitz Indian Tribe v. FERC, 186 Fed. App'x 806 (9th Cir. 2006).

60. See generally, e.g., Sierra Club v. Glickman, 156 F.3d 606 (5th Cir. 1998).

61. See generally, e.g., Sierra Club v. Van Antwerp, 661 F.3d 1147 (D.C. Cir. 2011); Miccosukee Tribe of Indians of Fla. v. United States, 566 F.3d 1257 (11th Cir. 2009); Miccosukee Tribe of Indians of Fla. v. United States, 528 F. Supp. 2d 1317 (S.D. Fla. 2007), aff'd in part, rev'd in part, 566 F.3d 1257 (11th Cir. 2009); Miccosukee Tribe of Indians of Fla. v. United States, 420 F. Supp. 2d 1324 (S.D. Fla. 2006).

62. See generally, e.g., Wild Fish Conservancy v. Kempthorne, 613 F. Supp. 2 d 1209 (E.D. Wash. 2009), rev'd sub nom. Wild Fish Conservancy v. Salazar, 628 F.3d 513 (9th Cir. 2010). 
California and Oregon; ${ }^{64}$ Lake Earl and Lake Talawa in California; ${ }^{65}$ the Little Truckee River in Nevada ${ }^{66}$ Mill Creek in California $;{ }^{67}$ the multistate Missouri River; ${ }^{68}$ the Muddy River/Warm Springs Area in Nevada $;{ }^{69}$ the Platte River in Nebraska $;{ }^{70}$ Pyramid Lake in Nevada $;{ }^{71}$ the Rio Grande River in New Mexico $;{ }^{72}$ the Salmon River Basin in Idaho $;{ }^{73}$ the Sacramento-San Joaquin Bay Delta in California; ${ }^{74}$ the San Pedro River in Arizona; ${ }^{75}$ the South Yuba River in California; ${ }^{76}$ Wildcat Creek

63. See generally, e.g., D'Olive Bay Restoration \& Pres. Comm., Inc. v. U.S. Army Corps of Eng'rs, 513 F. Supp. 2 d 1261 (S.D. Ala. 2007).

64. See generally, e.g., Bennett v. Spear, 520 U.S. 154 (1997); Pac. Coast Fed'n of Fishermen's Ass'ns v. U.S. Bureau of Reclamation, 426 F.3d 1082 (9th Cir. 2005); Kandra v. United States, 145 F. Supp. 2d 1192 (D. Or. 2001).

65. See generally, e.g., Pac. Shores Subdivision Cal. Water Dist. v. U.S. Army Corps of Eng'rs, 538 F. Supp. 2d 242 (D.D.C. 2008).

66. See generally, e.g., Carson-Truckee Water Conservancy Dist. v. Clark, 741 F.2d 257 (9th Cir. 1984).

67. See generally, e.g., San Bernardino Valley Audubon Soc'y v. FERC, 242 Fed. App’x 462 (9th Cir. 2007).

68. See generally, e.g., In re Operation of Mo. River Sys. Litig., 421 F.3d 618 (8th Cir. 2005); Am. Rivers v. U.S. Army Corps of Eng'rs, 271 F. Supp. 2d 230 (D.D.C. 2003).

69. See generally, e.g., Ctr. for Biological Diversity v. U.S. Fish \& Wildlife Serv., 900 F. Supp. 2d 1151 (D. Nev. 2012).

70. See generally, e.g., Platte River Whooping Crane Critical Habitat Maint. Trust v. FERC, 962 F.2d 27 (D.C. Cir. 1992).

71. See generally, e.g., Pyramid Lake Paiute Tribe of Indians v. U.S. Dep't of Navy, 898 F.2d 1410 (9th Cir. 1990).

72. See generally, e.g., Rio Grande Silvery Minnow v. Bureau of Reclamation, 601 F.3d 1096 (10th Cir. 2010).

73. See generally, e.g., W. Watersheds Project v. Matejko, 468 F.3d 1099 (9th Cir. 2006).

74. See generally, e.g., NRDC v. Salazar, 686 F.3d 1092 (9th Cir. 2012); San Luis \& DeltaMendota Water Auth. v. Salazar, 638 F.3d 1163 (9th Cir. 2011); NRDC v. Hous., 146 F.3d 1118 (9th Cir. 1998); In re Consol. Salmonid Cases, 791 F. Supp. 2d 802 (E.D. Cal. 2011); Coal. for a Sustainable Delta v. FEMA, 812 F. Supp. 2d 1089 (E.D. Cal. 2011); San Luis \& Delta-Mendota Water Auth. v. Salazar, 760 F. Supp. 2d 855 (E.D. Cal. 2010); Consol. Delta Smelt Cases, 717 F. Supp. 2d 1021 (E.D. Cal. 2010); Consol. Salmonid Cases, 713 F. Supp. 2d 1116 (E.D. Cal. 2010); Coal. for a Sustainable Delta v. FEMA, 711 F. Supp. 2d 1152 (E.D. Cal. 2010); San Luis \& DeltaMendota Water Auth. v. Salazar, 666 F. Supp. 2d 1137 (E.D. Cal. 2009); NRDC v. Kempthorne, 621 F. Supp. 2d 954 (E.D. Cal. 2009); NRDC v. Kempthorne, No. 1:05-CV-01207 OWW TAG, 2008 WL 5054115 (E.D. Cal. Nov. 19, 2008), superseded in part by NRDC v. Kempthorne, 621 F. Supp. 2d 954 (E.D. Cal. 2009), and clarified by NRDC v. Kempthorne, 627 F. Supp. 2d 1212 (E.D. Cal. 2009); Pac. Coast Fed'n of Fishermen's Ass'ns v. Gutierrez, 606 F. Supp. 2 d 1195 (E.D. Cal. 2008); Pac. Coast Fed'n of Fishermen's Ass'ns v. Gutierrez, 606 F. Supp. 2d 1122 (E.D. Cal. 2008); NRDC v. Kempthorne, 506 F. Supp. 2d 322 (E.D. Cal. 2007); NRDC v. Rodgers, 381 F. Supp. 2d 1212 (E.D. Cal. 2005); Westlands Water Dist. v. U.S. Dep't of Interior, Bureau of Reclamation, 850 F. Supp. 1388 (E.D. Cal. 1994).

75. See generally, e.g., Ctr. for Biological Diversity v. Salazar, 804 F. Supp. $2 d 987$ (D. Ariz. 2011); Ctr. for Biological Diversity v. U.S. Dep’t of Hous. \& Urban Dev., 541 F. Supp. 2d 1091 (D. Ariz. 2008); Ctr. for Biological Diversity v. Rumsfeld, 198 F. Supp. 2d 1139 (D. Ariz. 2002).

76. See generally, e.g., S. Yuba River Citizens League v. Nat'l Marine Fisheries Serv., 723 F. 
in Colorado; ${ }^{77}$ and the Willamette River in Oregon. ${ }^{78}$

\section{The ESA's Section 9 Prohibitions for Everyone}

The ESA's second set of protections for listed species comes in Section 9, which contains lists of prohibited activities. These prohibitions apply to "any person subject to the jurisdiction of the United States," $"$ with the ESA defining "person" to be:

an individual, corporation, partnership, trust, association, or any other private entity; or any officer, employee, agent, department, or instrumentality of the Federal Government, of any State, municipality, or political subdivision of a State, or of any foreign government; any State, municipality, or political subdivision of a State; or any other entity subject to the jurisdiction of the United States. ${ }^{80}$

Section 9 is thus broadly applicable to all individuals, businesses, and governments operating within the U.S.

"[W]ith respect to any endangered species of fish or wildlife" listed under the ESA, ${ }^{81}$ Section 9 makes it unlawful for any person to:

(A) import any such species into, or export any such species from the United States;

(B) take any such species within the United States or the territorial sea of the United States;

(C) take any such species upon the high seas;

(D) possess, sell, deliver, carry, transport, or ship, by any means whatsoever, any such species taken in violation of subparagraphs (B) and $(\mathrm{C})$;

(E) deliver, receive, carry, transport, or ship in interstate or foreign commerce, by any means whatsoever and in the course of a commercial activity, any such species;

(F) sell or offer for sale in interstate or foreign commerce any such species; or

Supp. 2d 1247 (E.D. Cal. 2010); S. Yuba River Citizens League v. Nat'l Marine Fisheries Serv., 629 F. Supp. 2d 1123 (E.D. Cal. 2009).

77. See generally, e.g., Riverside Irrigation Dist. v. Andrews, 568 F. Supp. 583 (D. Colo. 1983).

78. See generally, e.g., Audubon Soc'y of Portland v. Nat'l Marine Fisheries Serv., 849 F. Supp. 2d 1017 (D. Or. 2011).

79. 16 U.S.C. $§ 1538(a)(1)-(2)(2012)$.

80. Id. § 1532(13).

81. Id. § 1538(a)(1). 
(G) violate any regulation pertaining to such species or to any threatened species of fish or wildlife listed pursuant to [Section 4] and promulgated by the Secretary pursuant to authority provided by this chapter.

In turn, "with respect to any endangered species of plants," 83 Section 9 makes it unlawful for any person to:

(A) import any such species into, or export any such species from, the United States;

(B) remove and reduce to possession any such species from areas under Federal jurisdiction; maliciously damage or destroy any such species on any such area; or remove, cut, dig up, or damage or destroy any such species on any other area in knowing violation of any law or regulation of any State or in the course of any violation of a State criminal trespass law;

(C) deliver, receive, carry, transport, or ship in interstate or foreign commerce, by any means whatsoever and in the course of a commercial activity, any such species;

(D) sell or offer for sale in interstate or foreign commerce any such species; or

(E) violate any regulation pertaining to such species or to any threatened species of plants listed pursuant to [Section 4] and promulgated by the Secretary pursuant to authority provided by this chapter.

Finally, "[i]t is unlawful for any person subject to the jurisdiction of the United States to attempt to commit, solicit another to commit, or cause to be committed, any offense defined in this section., ${ }^{, 5}$

Several aspects of Section 9's prohibitions are worth further comment. First, Section 9's many restrictions on trade in listed species both help the U.S. to implement a number of international treaties related to wildlife, especially the Convention on International Trade in Endangered Species of Flora and Fauna (CITES), and acknowledge that trade can be a substantial driver of species extinctions. ${ }^{86}$ Second, Section

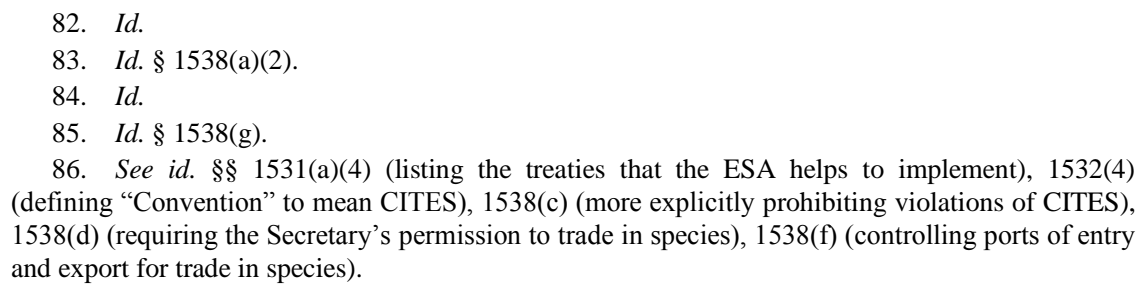


9's prohibitions apply to endangered species, ${ }^{87}$ the only prohibitions relevant to threatened species forbid violating the expert agencies' regulations. $^{88}$ This statutory distinction between threatened and endangered species acknowledges that USFWS and NMFS can write special regulations detailing the protections given or not given to threatened species, known as "Section 4(d) rules." 89 Nevertheless, as a result of the agencies' default regulation, threatened species receive all of the same protections that endangered species do unless the relevant expert agency promulgates a special regulation. ${ }^{90}$ Finally, just as federal agencies can receive permission to incidentally take listed species through the Section 7 consultation process, private individuals and entities and non-federal governments can acquire, pursuant to Section 10, a variety of different permits that allow activities that would otherwise violate Section 9. ${ }^{91}$ The most important of these is the Incidental Take Permit, ${ }^{92}$ but permits are also available for scientific research, ${ }^{93}$ to relieve hardships created by a species' listing, ${ }^{94}$ for subsistence hunting by Alaska Natives, ${ }^{95}$ for trade in pre-ESA artifacts, ${ }^{96}$ and for introductions of experimental populations. ${ }^{97}$

Outside of actual trade in species, the Section 9 prohibition that has received the most legal attention is the prohibition on "take." The ESA defines "take" to mean "harass, harm, pursue, hunt, shoot, wound, kill, trap, capture, or collect, or to attempt to engage in any such conduct." Of particular importance in the water context (and many other contexts), the expert agencies have defined "harm" to be "an act which actually kills or injures wildlife. Such act may include significant habitat modification or degradation where it actually kills or injures wildlife by significantly impairing essential behavioral patterns, including breeding,

87. Id. § 1538(a)(1)-(2).

88. Id. § 1538(a)(1)(G), (2)(E).

89. See id. $\S 1533(\mathrm{~d})$.

90. 50 C.F.R. $\S 17.31$ (a), (c) (2013). The USFWS's special 4(d) rules are codified at $i d$. $\S \S$ 17.40 to 17.48 ; for an example of a NMFS 4(d) rule for salmon that accommodates tribal treaty fishing rights, see $i d . \S 223.204$.

91. 16 U.S.C. $\$ 1539$ (2012).

92. Id. § 1539(a).

93. Id. § 1539(a)(1)(A).

94. Id. § 1539(b).

95. Id. $\$ 1539(\mathrm{e})$.

96. Id. $\S 1539(\mathrm{f}),(\mathrm{h})$.

97. Id. § 1539(j).

98. Id. § 1532(19). 
feeding or sheltering." 99 In addition, because Section 9 prohibits attempts and solicitation, courts have concluded that it prohibits thirdparty "takes" as well as direct takes. ${ }^{100}$ As a result, permitting agencies - such as state agencies that issue water rights - can be held responsible in some circumstances for the cumulative impact of the permitted private actions (such as water withdrawal and use) on ESAlisted species. ${ }^{101}$ This was the legal context for the Aransas Project case, discussed in Subpart B below.

Federal agencies, however, can also potentially run afoul of Section 9 as a result of their water management. For example, in the Apalachicola-Chattahoochee-Flint River (ACF) Basin shared among Alabama, Georgia, and Florida, the U.S. Army Corps operates a number of dams. ${ }^{102}$ One of these, the Jim Woodruff Lock and Dam, sits at the border of Georgia and Florida, where the Chattahoochee and Flint Rivers converge into the Apalachicola, which flows through the panhandle of Florida to the Gulf of Mexico, emptying at Apalachicola Bay. ${ }^{103}$ "Four federally-listed threatened and endangered species are present in the Apalachicola River downstream from Woodruff Dam: the threatened Gulf sturgeon, the endangered fat threeridge mussel, the threatened purple bankclimber mussel, and the threatened Chipola slabshell mussel." $" 104$

In the early years of the twenty-first century, during drought, the States of Alabama and Florida filed suit against the U.S. Army Corps of Engineers, asserting that the Corps was allowing too little water to pass through the Woodruff Dam, killing ESA-listed mussels downstream and thus resulting in a "take" in violation of Section 9. ${ }^{105}$ The U.S. District Court for the Northern District of Alabama, however, concluded that Florida had failed to show the causation necessary to hold the Army Corps liable under the ESA. ${ }^{106}$ Notably, the court first concluded that

99. 50 C.F.R. $§ 17.3$ (2013). The U.S. Supreme Court has upheld this definition against a facial challenge. Babbitt v. Sweet Home Chapter of Cmtys. for a Great Or., 515 U.S. 687 (1995).

100. E.g., Strahan v. Coxe, 127 F.3d 155, 163 (1st Cir. 1997).

101. See id. at 165-66 (holding the Massachusetts state permitting agencies liable under Section 9 for the cumulative impact of lobster pot fishermen on endangered Northern Right whales).

102. Alabama v. U.S. Army Corps of Eng'rs, 441 F. Supp. 2d 1123, 1125 (N.D. Ala. 2006).

103. Id. at $1124-25$.

104. Id. at 1125 .

105. Id. at 1125-26. See also Alabama v. U.S. Army Corps of Eng'rs, 424 F.3d 1117 (11th Cir. 2005).

106. Alabama v. U.S. Army Corps of Eng'rs, 441 F. Supp. 2d 1123, 1132-35, 1138 (N.D. Ala. 2006). 
"[n]o one disputes that protected mussels are dying by the hundreds, that more will die at 5,000 cfs ['cubic feet per second,' a measure of water flow], and that their habitat is being modified by the decreased flows so that they are facing death, harm, and harassment. Thus, the court finds that a take has occurred as that term is defined by" the ESA and its implementing regulations. ${ }^{107}$ However, despite the fact that the Army Corps controlled the flow of water through the Woodruff Dam, the court concluded that it had not caused the ESA take:

Florida urges this court to find that the Corps' choice as to the amount of water to retain upstream in storage versus the amount to release downstream to support protected mussels violates the anti-taking provision of the ESA. The court is not convinced that the predicament faced by these protected mussels rests at the feet of the Corps. Instead, the weight of evidence points to other causes for the exposure of the mussels and harm to their habitat. No one disputes that the ACF basin suffers from severe drought conditions. Evidence from FWS indicates that drought conditions have become more severe than droughts were in the years prior to the constructing of dams on these affected rivers. While the presence of these dams may have contributed in some ways to the effects of this year's drought, Florida offered no evidence on this point. Because of decreased rainfall and increased evaporation, the amount of water available in the ACF basin has fallen sharply. The court cannot hold the Corps responsible for the absence of rain.

As a result, the court refused to preliminarily enjoin the Army Corps's water management at the Woodruff Dam. ${ }^{109}$

\section{B. Water Rights, Water Management, and the ESA}

\section{Example \#1: The San Antonio \& Guadalupe Rivers and Aransas} Project v. Shaw

As was true for the Army Corps in the ACF Basin, Section 9 causation is the primary legal issue in Aransas Project v. Shaw, ${ }^{110}$ a case decided by the Southern District of Texas in March 2013. This case involved the whooping crane population that winters at the Aransas National Wildlife Refuge in southern Texas (the AWB flock). ${ }^{111}$ The

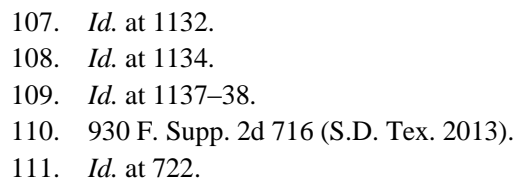


whooping crane was listed for protection under federal endangered species legislation that preceded the current ESA - as threatened in $1967^{112}$ and as endangered in $1970 .{ }^{113}$ The Refuge is located in the Guadalupe Estuary, also known as San Antonio Bay, and its proper functioning as whooping crane habitat depends on freshwater flows from the Guadalupe and San Antonio Rivers. ${ }^{114}$ As the court described:

The Refuge receives freshwater inflows from primarily two river sources, the San Antonio and the Guadalupe, each located to the north and slightly west of the area. The San Antonio river flows into the Guadalupe river system, and the Guadalupe river flows directly into the Refuge, emptying into the San Antonio bay .... The San Antonio and the Guadalupe river systems emerge from underground springs near San Antonio and run 250 miles southeast where they join together just before entering the San Antonio bay and flow into the AWB flock's winter habitat, that extends slightly north of the Refuge. These freshwater inflows come from a combination of spring flows and rainfall. $^{115}$

During the winter of 2008-2009, this area experienced severe drought. ${ }^{116}$ By the end of the winter, according to the court, 23 AWB whooping cranes had died and another 34 that left the area in the spring failed to return in the fall. ${ }^{117}$

According to the Southern District of Texas, the culprit, legally and factually, was the Texas Commission on Environmental Quality (TCEQ), which has responsibility in Texas for allocating water rights. As the district court explained, "The State of Texas owns its surface water, and this includes the water in the Guadalupe and the San Antonio River systems. Under Texas law, freshwater capture and use is regulated by the Texas Commission on Environmental Quality (TCEQ), a state agency. Through its permit process and regulatory powers, the TCEQ can affect the availability of freshwater to users along the river system." After the TCEQ refused the Aransas Project's request that it dedicate sufficient instream flow in the San Antonio and Guadalupe Rivers to protect the whooping cranes' habitat, the Aransas Project sued,

\footnotetext{
112. Notice of Public Hearing Regarding Wilderness Study, 32 Fed. Reg. 4001 (Mar. 11, 1967).

113. Bureau of Sport Fisheries and Wildlife, 35 Fed. Reg. 16047 (Oct. 13, 1970).

114. Aransas Project, 930 F. Supp. $2 d$ at 723.

115. Id. (footnotes omitted).

116. Id. at 724 .

117. Id.

118. Id. at 725. See also id. at 737-44 (discussing TCEQ's legal authority under Texas water
} law). 
arguing that the TCEQ's water management decisions had effectuated a "take" of the whooping cranes in violation of Section 9 of the ESA. ${ }^{119}$

The district court agreed. First, it concluded:

that the TCEQ defendants have the authority, power, and responsibility to manage water diversions, and the ESA requires that such management take into account the health and survival of the AWB whooping cranes. The Court finds further that TCEQ has refused to issue a permit to permit freshwater inflow for the protection of the AWB habitat and that S.B.3 either by definition or application will not protect the winter habitat of the AWB. ${ }^{120}$

Second, the court upheld the Aransas Project's theories of factual and proximate (legal) causation. ${ }^{121}$ The court's finding of legal causation (proximate causation) was particularly interesting because of the long chain of factual connections involved:

[A]t trial TAP offered essentially uncontroverted evidence to establish: (1) the TCEQ defendants are responsible for water permitting and water diversions from the San Antonio and Guadalupe River systems, and the increased water diversions have left less water for the cranes; (2) reduced water flows lead to high bay/estuary salinities (in excess of 30 to $40 \mathrm{ppt}$ in wide spread sampling); (3) high San Antonio bay/Guadalupe estuary salinities lead to a reduction in the availability of wolfberries, blue crabs, and fresh drinking water; (4) the reduced availability of the cranes' primary food sources, coupled with the expenditure of more energy to fly farther to search for food and freshwater, leads to malnourishment and death; and (5) TCEQ defendant's water practices caused the death of at least 23 whooping cranes in the 2008-2009 winter. That is, the mortality of the Whooping Crane population is directly attributable to the lack of freshwater inflows to these crucian estuaries. ${ }^{122}$

The district court's decision is currently on appeal to the U.S. Court of Appeals for the Fifth Circuit, ${ }^{123}$ and this extended chain of proximate causation is likely to be a key focus of the Fifth Circuit's analysis.

Regardless of the Fifth Circuit's eventual decision, however, this case demonstrates how the exercise of state-issued water rights and state

\footnotetext{
119. Id. at 725 (citing 15 U.S.C. $§ 1538$ (2012)).

120. Id. at 743 .

121. Id. at $745-75$.

122. Id. at 731 .

123. See, e.g., Transcript of Oral Argument at 1, Aransas Project v. Shaw, - F.3d - (Aug. 8, 2013) (No. 13-40317).
} 
water management decisions (the refusal to establish an instream flow) can come directly into conflict with the ESA. Here, the exercise of state water rights during a drought reduced river flows to the estuary, setting off a cascade of chemical, biological, and ecosystem reactions that ultimately affected — and allegedly killed-ESA-listed species.

\section{Example \#2: The Sacramento-San Joaquin Bay Delta}

The Sacramento-San Joaquin Bay Delta in northern California, also known as the California Bay Delta, is created by a confluence of the Sacramento and San Joaquin Rivers and is the home of the massive Central Valley Project (CVP, U.S. Bureau of Reclamation) and State Water Project (SWP, California). ${ }^{124}$ "Withdrawals of water from the Bay Delta provide drinking water to about 25 million Californians and irrigation water for about 750,000 acres of crops." 125 However, the Bay Delta is also home to the Delta smelt (Hypomesus transpacificus), a species of small fish that has been listed as threatened under the ESA since $1992 .^{126}$

Given the Bureau of Reclamation's operation of the CVP and the presence of the Delta smelt, the CVP is subject to Section 7 of the ESA. Despite precipitous declines in the smelt's populations, however, the USFWS in 2005 issued a Biological Opinion that concluded that the CVP's operations would not jeopardize the Delta smelt's continued existence. $^{127}$

The Natural Resources Defense Council (NRDC) challenged this conclusion on the grounds that the USFWS had not used the best available science because, inter alia, it had not considered the effects of climate change on the Bay Delta system. ${ }^{128}$ The U.S. District Court for the Eastern District of California agreed, ${ }^{129}$ and on June 1, 2007, it granted summary judgment in the NRDC's favor. ${ }^{130}$

In light of this decision and trawls in the system in spring 2007 that found only twenty-five Delta smelt, "on May 31, 2007, the California

\footnotetext{
124. NRDC v. Kempthorne, 506 F. Supp. 2d 322, 328 (E.D. Cal. 2007).

125. Robin Kundis Craig, Environmental LaW in ConteXt: Cases and Materials 414 (3d ed. 2012).

126. Kempthorne, 506 F. Supp. 2d at 328 \& n.1 (citing 58 Fed. Reg. 12863 (Mar. 5, 1993)).

127. Id. at $328-29$.

128. Id. at 367 .

129. Id. at $367-70$.

130. NRDC v. Kempthorne, No. 1:05-cv-1207 OWW TAG, 2007 WL 1623826, at *1 (E.D. Cal. June 1, 2007).
} 
Department of Water Resources announced that it would stop pumping at SWP facilities in order to provide the maximum benefit to the Delta smelt." 131 In June, the CWP reduced its pumping to about $10 \%$ of normal, but more Delta smelt deaths resulted. ${ }^{132}$ District Court Judge Oliver Wanger's final injunction in December 2007 reduced the amount of water withdrawn from the Bay Delta by about 35\%, although he eventually (2011) allowed the Bay Delta pumps to operate at $80 \%$ of normal. ${ }^{133}$ This litigation also prompted a direct (but unsuccessful) constitutional attack on the ESA itself, alleging that application of the ESA to the intrastate Delta smelt violates the Commerce Clause. ${ }^{134}$

Perhaps ironically, however, the Ninth Circuit has also decided that a number of the Bureau of Reclamation's water contract renewals for the CVP are not subject to Section 7 of the ESA because the Bureau has no discretion in the renewal process. ${ }^{135}$ Nevertheless, in combination with continued drought and climate change impacts on California's snow pack, Judge Wanger's 2007 decisions helped to force water rationing throughout California. ${ }^{136}$ In particular, farmers previously dependent on the CVP and SWP have been coping with drought and reduced water deliveries ever since 2007, requiring them to decide how much of what kinds of crops to grow, to seek other sources of water such as purchasing water or pumping groundwater, and to invest in more water-efficient irrigation systems, such as drip irrigation. ${ }^{137}$ Such shortages are projected to last at least into 2014 , and a zero allocation is possible. ${ }^{138}$

\section{Example \#3: The Klamath River}

The Klamath River Basin straddles the Oregon-California border. In 1905, Congress authorized the Klamath River Project pursuant to the 1902 Reclamation Act, and, with the State of Oregon's full support, the U.S., acting through the U.S. Bureau of Reclamation, appropriated all

\footnotetext{
131. CRAIG, supra note 125, at 414.

132. Id.

133. Id. at $414-15$.

134. San Luis \& Delta-Mendota Water Auth. v. Salazar, 638 F.3d 1163, 1176-77 (9th Cir.

135. NRDC v. Salazar, 686 F.3d 1092, 1098-1100 (9th Cir. 2012).

136. CRAIG, supra note 125, at 414-15.

137. See Steve Adler, Farm Water Shortages Could Linger into 2014, AgAlERT (June 26, 2013), http://www.agalert.com/story/?id=5702 (last visited Mar. 30, 2014).

138. Id
} 2011). 
necessary Oregon state water rights for the project. ${ }^{139}$ This reclamation project provides irrigation water to about 240,000 acres of farms in southern Oregon ${ }^{140}$ and consists of a number of dams and reservoirs. ${ }^{141}$ The main reservoir for the system is Upper Klamath Lake, which is also home to two species of fish listed as endangered under the ESA in 1988: the Lost River sucker and the short-nosed sucker. ${ }^{142}$ The lowest dam on the system, the Iron Gate Dam, blocks the migration of salmon from the Pacific Ocean upstream into the rest of the Klamath River system, and as a result of this fact and habitat degradation from water diversions, in 1997 the NMFS listed the Southern Oregon/Northern California Coast coho salmon (SONCCC salmon) under the ESA as a threatened species. $^{143}$

The Klamath Basin is another system where the courts have deemed the exercise of individual water rights to be in direct conflict with the ESA, and - as with California's CVP/SWP - these conflicts have been mediated largely through Section 7 because of the Bureau of Reclamation's involvement. Such conflicts first came to a head in 2000, when fishermen and conservation interests filed a lawsuit in the U.S. District Court for the Northern District of California challenging the Bureau's continued deliveries of irrigation water to farmers under its 2000 Operations Plan in light of the impacts on the SONCCC salmon. ${ }^{144}$ The district court concluded that the Bureau of Reclamation had not complied with the ESA's Section 7 formal consultation requirement. ${ }^{145}$ As a result, the Northern District of California found:

[T]hat [the] plaintiffs [were] entitled to injunctive relief because the Bureau of Reclamations committed a substantial procedural violation of the Endangered Species Act in operating Klamath Project for an entire year pursuant to its 2000 Operations Plan without completing a biological assessment of the likely impact of that plan on the threatened coho salmon or its critical habitat, or engaging in consultation as the

139. Robert W. Adler, Robin K. Craig, \& NoAh D. Hall, Modern Water LaW: Private Property, PUBLIC Rights, AND ENVIRONMENTAL PROTECTIONS 634 (2013).

140. Id.

141. Kandra v. United States, 145 F. Supp. 2d 1192, 1196-97 (D. Or. 2001).

142. Id. at 1196 (citing 50 C.F.R. Part 17 (1988)).

143. Id. at 1197 (citing 50 C.F.R. Part 227 (1997)).

144. Pac. Coast Fed'n of Fishermen's Ass'ns v. U.S. Bureau of Reclamation, 138 F. Supp. 2d 1228, 1232, 1234-35 (N.D. Cal. 2001).

145. Id. at $1242-47$. 
Act and the regulations specifically required it to do. ${ }^{146}$

In April 2001, it enjoined the Bureau of Reclamation:

[F]rom sending irrigation deliveries from Klamath Project whenever Klamath River flows at Iron Gate Dam drop below the minimum flows recommended in the Hardy Phase I report, until such time as the Bureau completes a concrete plan to guide operations in the new water year, and consultation concerning that plan is completed, either by (1) formal consultation to a "no jeopardy" finding by the NMFS, or (2) the Bureau's final determination, with the written concurrence of the NMFS, that the proposed plan is unlikely to adversely affect the threatened coho salmon.

As it turned out, 2001 was a severe drought (critically dry) year in the region, and, in compliance with the Northern District of California's injunction, the Bureau terminated delivery of water to irrigators on April $6,2001 .^{148}$

In addition, the Bureau engaged in proper consultation with the USFWS and NMFS, and its 2001 Annual Operation Plan for the Klamath Project was based on Biological Opinions from the USFWS and NMFS that severely limited irrigation water deliveries in critically dry years in order to protect the listed fish. ${ }^{149}$ In response, irrigators sued the U.S. in the U.S. District Court for the District of Oregon to enjoin the Bureau of Reclamation from implementing its 2001 Plan. ${ }^{150}$ The district court, however, upheld both the Biological Opinions and the 2001 Plan, ${ }^{151}$ concluding that:

While the court sympathizes with plaintiffs and their plight, I am bound by oath to uphold the law. The law requires the protection of suckers and salmon as endangered and threatened species and as tribal trust resources, even if plaintiffs disagree with the manner in which the fish are protected or believe that they inequitably bear the burden of such protection.

The scarcity of water in the Klamath River Basin is a situation likely to reoccur. It is also a situation which demands effort and resolve on the part of all parties to create solutions that provide water for the

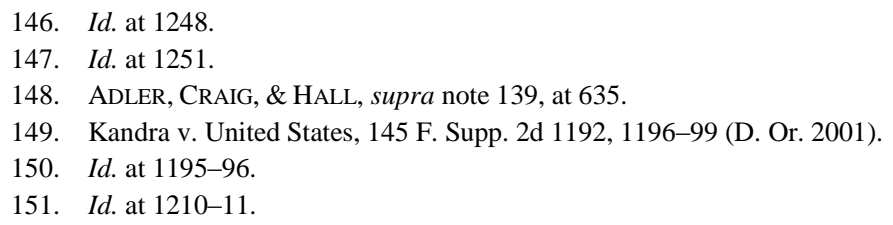


necessary protection of fish, wildlife and tribal trust resources, as well as the agricultural needs of farmers and their communities. Continued litigation is not likely to assist in such a challenging endeavor. This court hopes and expects that the parties and other entities necessary to long-term solutions will continue to pursue alternatives to meet the needs of the Klamath River Basin. ${ }^{152}$

The Bureau was nevertheless able to again deliver some water to the irrigators in July 2001, and "the farmers received about $\$ 40$ million in federal and state disaster aid."153 However, the Northern District of California and Ninth Circuit have continued to enjoin irrigation water diversions in order to protect the ESA-listed fish, especially the SONCCC salmon. ${ }^{154}$

The Klamath Basin, however, may be transitioning to a new balance between the ESA and water users. ${ }^{155}$ PacifiCorp operates many of the dams in the Klamath Basin for hydropower, and its federal licenses for such operations expired in 2006. ${ }^{156}$ The relicensing process through the Federal Energy Regulatory Commission (FERC) is subject to all current environmental laws, including the ESA, and PacifiCorp concluded that compliance with these statutes was likely to make the dams unprofitable, allowing for the possibility of removing the dams. ${ }^{157}$ Moreover, the negotiation process for the FERC relicensings brought all of the interests in the Klamath Basin together, allowing them to eventually, in 2010, negotiate two agreements that would remove four dams and better balance water use among the irrigators, tribes, and fish and wildlife needs. ${ }^{158}$ Implementation of these agreements now depends on Congress - but the irrigators continue to pursue lawsuits against the U.S. and Bureau of Reclamation for breach of contract and unconstitutional takings of their water rights based on the terminations of water deliveries. ${ }^{159}$

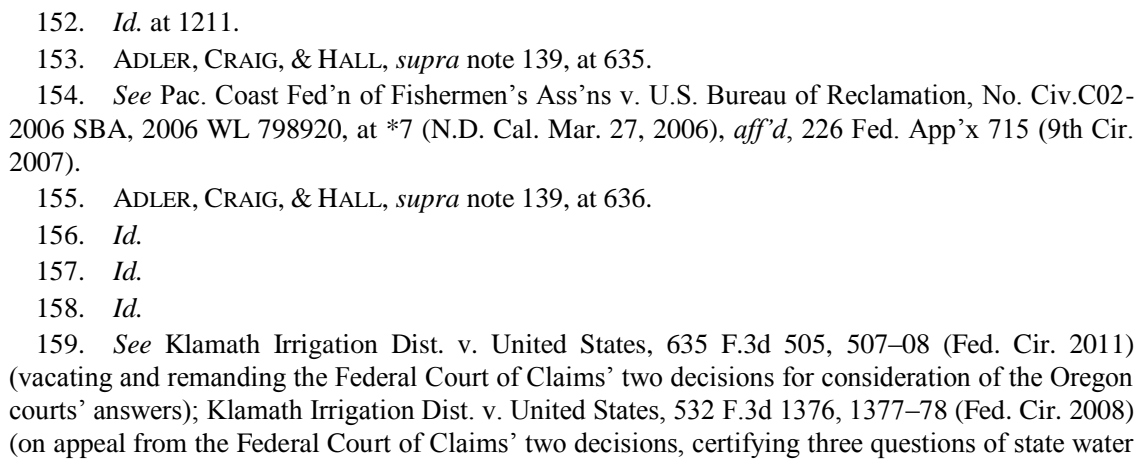

159. See Klamath Irrigation Dist. v. United States, 635 F.3d 505, 507-08 (Fed. Cir. 2011) (vacating and remanding the Federal Court of Claims' two decisions for consideration of the Oregon courts' answers); Klamath Irrigation Dist. v. United States, 532 F.3d 1376, 1377-78 (Fed. Cir. 2008) (on appeal from the Federal Court of Claims' two decisions, certifying three questions of state water 


\section{Example \#4: The Edwards Aquifer}

The Edwards Aquifer is located in central Texas, underlying eight Texas counties and acting as the exclusive water supply for the City of San Antonio. ${ }^{160}$ It also supplies irrigation water to a number of farmers. ${ }^{161}$ The aquifer discharges into the Comal and San Marcos Springs, which are home to several ESA-listed species. ${ }^{162}$ "These species include the fountain darter (Etheostoma fonticola), the San Marcos salamander (Eurycea nana), the San Marcos gambusia (Gambusia georgi), the Texas blind salamander (Typhomolge athbuni), the Comal Springs dryopid beetle (Stygompamus comalensis), the Comal Springs riffle beetle (Heterelmis comalensis), and Texas wild-rice (Zizania texana) (collectively, 'the Edwards species')."163 These species have been the subject of litigation since at least 1991, including lawsuits against the City of San Antonio alleging that the city's pumping of the aquifer is causing Section 9 takes at the springs ${ }^{164}$ and allegations that other individual groundwater pumpers were causing Section 9 takes of the listed species. ${ }^{165}$ Thus, the Edwards Aquifer is another water resource where individual water rights appear to conflict with ESA-listed species.

However, the Texas Legislature shifted the legal focus of this conflict away from ESA preemption to its own innovations in state water

\footnotetext{
law to the Oregon courts); Klamath Irrigation Dist. v. United States, 75 Fed. Cl. 677, 683-85 (Fed. Cl. 2007) (holding that the sovereign acts doctrine provided the Bureau of Reclamation with a complete defense to the breach of contract claims based on its implementation of the ESA); Klamath Irrigation Dist. v. United States, 67 Fed. Cl. 504, 531-35 (Fed. Cl. 2005) (holding that the irrigators had only breach of contract claims, not constitutional takings claims), order modified, $68 \mathrm{Fed}$. Cl. 119 (Fed. Cl. 2005) (regarding the required status report), certification of interlocutory appeal denied, 69 Fed. Cl. 160 (Fed. Cl. 2005); Klamath Irrigation Dist. v. United States, 64 Fed. Cl. 328, 336 (Fed. Cl. 2005) (allowing fishermen's organization to intervene in the constitutional takings litigation); Klamath Irrigation Dist. v. United States, 227 P.3d 1145, 1169 (Or. 2010) (en banc) (concluding, on certification from the Federal Circuit, that irrigators could establish property rights in the water despite the United States' appropriations from the state); Klamath Irrigation Dist. v. United States, 202 P.3d 159, 165 (Or. 2009) (on certification from the Federal Circuit, accepting three questions for resolution under state law).

160. Fred O. Boadu, Bruce M. McCarl, \& Dhazn Gillig, An Empirical Investigation of Institutional Change in Groundwater Management in Texas: The Edwards Aquifer Case, 47 NAT. RESOURCES J. 117, 120, 135 (2007).

161. Id. at 120 .

162. Sierra Club v. City of San Antonio, 112 F.3d 789, 791 (5th Cir. 1997).

163. Shields v. Babbitt, 229 F. Supp. 2d 638, 645 (W.D. Tex. 2000), judgment vacated sub nom. Shields v. Norton, 289 F.3d 832 (5th Cir. 2002), cert. denied sub nom. Schuehle v. Norton, 537 U.S. 1071 (2002).

164. Sierra Club, 112 F.3d at 791-92.

165. Shields, 229 F. Supp. $2 d$ at 646-47.
} 
law. In a 1993 ESA-based decision, the U.S. District Court for the Western District of Texas effectively federalized management of the Edwards Aquifer unless the State of Texas acted to regulate the aquifer in compliance with the ESA. ${ }^{166}$ In an attempt to avoid this federal domination of the aquifer, ${ }^{167}$ the Texas Legislature enacted the Edwards Aquifer Authority Act in 1993, which the Texas Supreme Court unanimously upheld as facially constitutional in $1996 .{ }^{168}$

The Act creates the Edwards Aquifer Authority, which regulates groundwater withdrawals from the aquifer. ${ }^{169}$ Specifically:

The Act imposes an aquifer-wide cap on water withdrawals by nonexempt wells of 450,000 acre-feet of water per year through the year 2007 and 400,000 acre-feet per year thereafter. The Authority can increase the withdrawal caps if it determines that additional water supplies are safely available from the aquifer. The Authority will allocate these caps among wells by a permit system. However, all wells producing no more than 25,000 gallons of water a day for domestic or livestock purposes are exempt from the permit system and the caps. This exemption allows all landowners, except those within or serving a platted subdivision, to drill wells for household purposes, watering animals, or irrigating a family garden. ${ }^{170}$

While the permitting program gives deference to existing users of water from the Edwards Aquifer, it also allows the Authority to reduce those established uses. ${ }^{171}$

The Edwards Aquifer story demonstrates that conflicts between state water rights and the ESA can alter state water law through mechanisms other than federal preemption. It also demonstrates that water rights holders who view those water rights as absolute property rights can extend litigation about ESA-conflicted water resources for decades.

166. See Sierra Club v. Lujan, No. MO-91-CA-069, 1993 WL 151353, at*33-35 (W.D. Tex. Feb. 1, 1993).

167. Catherine Bennett, Groundwater Rights and the Endangered Species Act: Potential ESA Suits When S.B. 332 Is Implemented, 42 TEX. ENVTL. L.J. 151, 163-65 (2012); Matthew Carson Cottingham Miles, Water Wars: A Discussion of the Edwards Aquifer Water Crisis, 6 S.C. ENVTL. L.J. 213, 225-27 (1997) (tracing the creation of the Edwards Aquifer Authority to the U.S. District Court for the Western District of Texas's 1993 decision in Sierra Club v. Lujan, No. MO-91-CA069, 1993 WL 151353, at*8-9 (W.D. Tex. Feb. 1, 1993)).

168. Sierra Club v. City of San Antonio, 112 F.3d 789, 792 (5th Cir. 1997); Barshop v. Medina Cnty. Underground Water Conservation Dist., 925 S.W.2d 618, 623 (Tex. 1996).

169. Barshop, 925 S.W.2d at 624.

170. Id. (citing Act of May 30, 1993, 73d Leg., R.S., ch. 626, §§ 1.03(9), 1.14(b), (c), (d), 1.16(c), 1.33, 1993 Tex. Gen. Laws 2355, as amended by Act of May 29, 1995, 74th Leg., R.S., ch. 261, 1995 Tex. Sess. Law Serv. 2505).

171. Id. at $624 \&$ n.2. 
Existing water users who have either been denied permits or been issued permits to pump reduced amounts of water from the Edwards Aquifer have sued continuously to stop implementation of the Act. ${ }^{172}$ Moreover, while the Edwards Aquifer Authority has continued to issue permits, the Texas Court of Appeals in August 2013 deemed the Authority's limited permits to be an unconstitutional taking of landowners' rights to groundwater without compensation. ${ }^{173}$ The court amended its opinionbut not its conclusion—in November 2013. ${ }^{174}$

\section{Beyond Specific Examples: A Nationwide Snapshot of ESA-Water Law Conflicts}

As the discussions throughout this Part indicate, water management in a number of water basins in the U.S., both East and West, depends at least in part on the ESA. Many of these water systems, moreover, have witnessed repeated and significant conflicts between human water use and management and the demands of the ESA, leading in several systems to reduced human water use and direct impacts on individual state-law and contractual water rights.

Such conflicts are likely only to increase in the future. First, as the Eastern District of California insisted for the Sacramento-San Joaquin Bay Delta, climate change is increasingly affecting water supplies in various parts of the U.S., generally for the worse. Climate change impacts include reduced rain, reduced snowpack, earlier snowmelt, and severe storm events preceded and followed by drought and are likely to be worst in the West. ${ }^{175}$ Increasing water temperatures and reduced flows have already affected energy production throughout the U.S., and coastal water supplies in places like Florida are already experiencing salt-water intrusion that sea-level rise will only exacerbate. ${ }^{176}$ As climate

172. E.g., Edwards Aquifer Auth. v. Day, 274 S.W.3d 742 (Tex. App. 2008), aff'd, 369 S.W.3d 814 (Tex. 2012); In re Edwards Aquifer Auth., 217 S.W.3d 581 (Tex. App. 2006); Edwards Aquifer Auth. v. Chem. Lime, Ltd., 212 S.W.3d 683 (Tex. App. 2006), rev'd, 291 S.W.3d 392 (Tex. 2009); Edwards Aquifer Auth. v. Peavy Ranch, 199 S.W.3d 312 (Tex. App. 2006); Edwards Aquifer Auth. v. Bragg, 21 S.W.3d 375 (Tex. App. 2000), aff'd, 71 S.W.3d 729 (Tex. 2002).

173. Edwards Aquifer Auth. v. Bragg, No. 04-11-00018-CV, 2013 WL 4535935, at*21 (Tex. App. Aug. 28, 2013), opinion withdrawn \& superseded on denial of rehearing, Edwards Aquifer Auth. v. Bragg, No. 04-11-00018-CV, 2013 WL 5989430 (Tex. App. Nov. 13, 2013).

174. Edwards Aquifer Auth. v. Bragg, No. 04-11-00018-CV, 2013 WL 5989430, at *14-22 (Tex. App. Nov. 13, 2013).

175. Water Resources: Climate Impacts on Water Resources, EPA, http://www.epa.gov/climate change/impacts-adaptation/water.html (last updated Sept. 9, 2013).

176. Id. 
change continues to alter water systems, it will increasingly stress both human water use and the other species that depend on the water, increasing the potential for ESA-water conflicts.

At the same time, the population of the U.S. is growing, especially in cities. Researchers reported in 2008 that "[t]he U.S. population now exceeds 300 million, and it is projected to almost double in the next 50 years." ${ }^{\prime 17}$ In addition, the populations of most major cities will probably increase by at least $50 \%$ by $2030 .{ }^{178}$ These increasing population pressures are second only to climate change across a variety of scenarios in their ability to increase water stress throughout the U.S., ${ }^{179}$ again presaging increasing ESA-water conflicts.

Other factors can contribute to future ESA-water conflicts. Increasing populations in cities, for example, means increased conversion of farms, wetlands, and forests to urban and suburban uses, which can affect both water availability and water quality. ${ }^{180}$ In addition, water users are overpumping ("mining") many of the nation's underground aquifers, threatening that source of water supply, reducing or eliminating alternatives to the surface water systems that species mostly depend upon, reducing or eliminating groundwater-fed surface waters, and causing land subsidence. ${ }^{181}$ Both of these trends, like climate change and population changes, are likely to exacerbate existing ESAwater conflicts.

The Aransas Project decision, therefore, is likely to be the first of many where courts are forced to decide the exact relationship between state water law and private water rights, on the one hand, and the ESA's requirements, on the other. To date, the legal relationship between the ESA and state water law has mostly been submerged (pun intended) because ESA-water conflicts have generally arisen in the context of federal water projects, with federal agencies holding state water rights, and hence have been mediated by the operations of Section 7 . The question of federal preemption never arises: the federal agency holds state water rights pursuant to one federal statute (the Reclamation Act,

177. Ge Sun et al., Impacts of Climate Change, Population Growth, Land Use Change, and Groundwater Availability on Water Supply and Demand Across the Conterminus U.S., 6 WATERSHED UPDATE 2, 3 (May-Aug. 2008), available at http://awra.org/committees/techcom/water shed/pdfs/AWRA\%20H\&WM_2008_2_climatechange.pdf.

178. Id.

179. Id. at 26 .

180. Id. at $10-11$.

181. Robert Glennon, Water Follies: Groundwater Pumping and the Fate of AMERICA'S FRESH WATERS 24-34, 209-24 (2002). 
dam authorizing legislation, etc.) and must comply with another federal statute, the ESA, in exercising them. Moreover, as a practical matter, the Section 7 consultation process can often mitigate conflicts that exist between the exercise of the federal agency's water rights and species protections, either through reasonable and prudent alternatives or Incidental Take Statements or both.

However, as the Aransas Project illustrates, in water systems without (or at least not dominated by) federal water projects, exercise of state water rights by state government agencies, municipalities, and private entities can also create conflicts with ESA-listed species. Where there is no federal involvement, moreover, these conflicts necessarily arise under ESA Section 9. As such, the exercise of state water rights in these circumstances directly pits a state law property right against a federal law prohibition. Federal preemption thus becomes the logical legal framework for analyzing these conflicts, especially in the absence of a Section 10 permit, and it is to that framework that this Article now turns.

\section{FEDERAL PREEMPTION: AN OVERVIEW}

Federal preemption derives from the U.S. Constitution's Supremacy Clause, which states that " $[\mathrm{t}]$ he Constitution and the Laws of the United States which shall be made in Pursuance thereof . . . shall be the Supreme Law of the Land; . . . any Thing in the Constitution or Laws of any State to the Contrary notwithstanding." 182 As many courts have pointed out, "The Supremacy Clause of the Constitution ... invalidates state laws that 'interfere with, or are contrary to,' federal law." 183 However, out of respect for the states, the U.S. Supreme Court begins its preemption analyses with a presumption that Congress did not intend to preempt state law, particularly in areas-like wildlife regulation-that traditionally have been the states' prerogative. ${ }^{184}$

There are three main ways in which federal law can nevertheless preempt state law. First, Congress can expressly preempt state law ${ }^{185}$ for example, by explicitly stating in a federal statute that certain kinds of

182. U.S. CONST. art. VI, cl. 2.

183. Nat'l Audubon Soc'y v. Davis, 307 F.3d 835, 851 (9th Cir. 2002) (citing Hillsborough Cnty., Fla. v. Automated Med. Labs., Inc., 471 U.S. 707, 712 (1985) (quoting Gibbons v. Ogden, 22 U.S. (9 Wheat.) 1, 211 (1824))).

184. E.g., Ray v. Atl. Richfield Co., 435 U.S. 151, 157 (1978) (quoting Rice v. Santa Fe Elevator Corp., 331 U.S. 218, 230 (1947); Jones v. Rath Packing Co., 430 U.S. 519, 525 (1977)).

185. Ray, 435 U.S. at 157; Lorillard Tobacco Co. v. Reilly, 533 U.S. 525, 541 (2001). 
state laws are preempted. ${ }^{186}$

Second, Congress can implicitly preempt state law. Implicit preemption analysis is the most complex kind of preemption analysis because the U.S. Supreme Court has recognized several different kinds of implicit preemption. Most sweeping is field preemption, where " $\mathrm{t}] \mathrm{he}$ scheme of federal regulation [is] so pervasive as to make reasonable the inference that Congress left no room for the States to supplement it"i.e., that Congress "occupies the field." ${ }^{187}$ For example, the Supreme Court has held that the Natural Gas Act of 1938 occupies the field of interstate natural gas regulation because it is a "comprehensive scheme" of federal regulation that gives "exclusive jurisdiction" to the Federal Energy Regulatory Commission. ${ }^{188}$

Similarly, when federal interests dominate over state interests, the courts will often hold that federal law implicitly preempts state law. ${ }^{189}$ For example, the U.S. Supreme Court has held that the federal government's interest in claims of fraud on the Food and Drug Administration (FDA) under the Food, Drug, and Cosmetic Act is so strongly federal that it preempts state common law fraud claims on the same subject. ${ }^{190}$ Similarly, Congress has a long history of preempting state law when it comes to regulating sea-going vessels and naval warships, because both navigation on the high seas and national defense are considered pervasive federal interests. ${ }^{191}$

In a third type of implicit preemption, courts will find that federal law implicitly preempts state law if the state law gets in the way of the federal law. More specifically, preemption occurs if "the object sought to be obtained by the federal law and the character of obligations imposed by it . . . reveal" Congress's intent to preempt state law. ${ }^{192}$

186. See, e.g., Fed. Boat Safety Act of 1971, 46 U.S.C. $§ 4306$ (2012) (providing that "a State or political subdivision of a State may not establish, continue in effect or enforce a law or regulation establishing a recreational vessel or associated equipment performance or other safety standard or imposing a requirement for associated equipment ... that is not identical to a regulation prescribed under" the Act).

187. Rice, 331 U.S. at 230 (citing Pa. R. Co. v. Pub. Serv. Comm'n, 250 U.S. 566, 569 (1919); Cloverleaf Butter Co. v. Patterson, 315 U.S. 148, 156 (1942)); Ray, 435 U.S. at 157.

188. Schneidewind v. ANR Pipeline Co., 485 U.S. 293, 300-04 (1988).

189. See, e.g., Buckman Co. v. Plaintiffs' Legal Comm'n, 531 U.S. 341, 351-52 (2001).

190. Id. at 347-48.

191. E.g., Lake Carriers' Ass'n v. MacMullan, 406 U.S. 498, 502, 506 (1972); Ray, 435 U.S. at 160-68 (1978); United States v. Locke, 529 U.S. 89, 106, 115-17 (2000).

192. Rice, 331 U.S. at 230 (citing S. Ry. Co. v. R.R. Comm'n, 236 U.S. 439, 446 (1915); Charleston \& W.C. Ry. Co. v. Varnville Furniture Co., 237 U.S. 597, 601-04 (1915); N.Y. Cent. R. Co. v. Winfield, 244 U.S. 147, 148 (1917); Napier v. Atl. Coast Line R.R. Co., 272 U.S. 605, 611 
Thus, for example, not only did the federal government have a strong interest in fraud-on-the-FDA cases, but, under the Food, Drug, and Cosmetic Act, "the federal statutory scheme amply empowers the FDA to punish and deter fraud against the Administration," and "[t]he balance sought by the Administration can be skewed by allowing fraud-on-theFDA claims under state tort law." 193

Finally, the courts have recognized conflict preemption as the irreducible form of federal preemption. Under conflict preemption, "[e]ven if Congress has not completely foreclosed state legislation in a particular area, a state statute is void to the extent that it actually conflicts with a valid federal statute."194 Importantly, "neither an express preemption provision nor a saving clause "bar[s] the ordinary working of conflict pre-emption principles."

Nevertheless, conflict preemption does create the issue of how to identify an "actual conflict" between state and federal law. Federal courts find that such conflicts exist primarily in two situations. First, a conflict exists "where compliance with both federal and state regulations is a physical impossibility ...."196 Second, a conflict between state and federal law exists if the state "law stands as an obstacle to the accomplishment and execution of the full purposes and objectives of Congress." "What is a sufficient obstacle is a matter of judgment, to be informed by examining the federal statute as a whole and identifying its purpose and intended effects ....",198

Thus, courts enjoy considerable discretion in discerning such "obstacles," but some conflicts between state and federal law are nevertheless fairly obvious. For example, federal bankruptcy law generally gives first priority to federal claims. ${ }^{199}$ When an Ohio bankruptcy statute ranked federal claims fifth in priority, it clearly

\footnotetext{
(1926)); Ray, 435 U.S. at 157-58.

193. Buckman, 531 U.S. at 348.

194. Ray, 435 U.S. at 158; see also Lorillard Tobacco Co. v. Reilly, 533 U.S. 525, 541 (2001) (noting that "[s]tate action may be foreclosed ... by implication because of a conflict with a congressional enactment ....").

195. Buckman, 531 U.S. at 352 (quoting Geier v. Am. Honda Motor Co., 529 U.S. 861, 869 (2000)).

196. Fla. Lime \& Avocado Growers, Inc. v. Paul, 373 U.S. 132, 142-43 (1963); Ray, 435 U.S. at 158 .

197. Hines v. Davidowitz, 312 U.S. 52, 67 (1941); see also Ray, 435 U.S. at 158; Jones v. Rath Packing Co., 430 U.S. 519, 526 (1977); De Canas v. Bica, 424 U.S. 351, 363 (1976).

198. Crosby v. Nat'1 Foreign Trade Council, 530 U.S. 363, 373 (2000).

199. 31 U.S.C. $§ 3713(a)(1)(A)(i i i)(2012)$.
} 
conflicted with federal bankruptcy law and was preempted. ${ }^{200}$

\section{THE ESA’s PREEMPTION OF STATE WATER LAW}

\section{A. Express Preemption of State Law by the ESA}

The ESA expressly preempts state law in certain circumstances. Specifically, Section 6(f) of the Act states that:

Any State law or regulation which applies with respect to the importation or exportation of, or interstate or foreign commerce in, endangered species or threatened species is void to the extent that it may effectively (1) permit what is prohibited by this chapter or by any regulation which implements this chapter, or (2) prohibit what is authorized pursuant to an exemption or permit provided for in this chapter or in any regulation which implements this chapter. This chapter shall not otherwise be construed to void any State law or regulation which is intended to conserve migratory, resident, or introduced fish or wildlife, or to permit or prohibit sale of such fish or wildlife. Any State law or regulation respecting the taking of an endangered species or threatened species may be more restrictive than the exemptions or permits provided for in this chapter or in any regulation which implements this chapter but not less restrictive than the prohibitions so defined. ${ }^{201}$

Courts have concluded that this section constitutes an express declaration of congressional intent to have the ESA preempt state law. ${ }^{202}$ Although the provision expressly allows states to continue to regulate-and hence simultaneously operates as a "savings clause"-states cannot "relax requirements of federal law or contravene terms of federal permit or exemption.",203

Most of the case law involving the ESA's express preemption provision has involved state laws governing species conservation, hunting, trapping, fishing, and international trade in fish and wildlifesubjects, in other words, to which the ESA directly speaks. Moreover, these cases closely hew to Section 6(f)'s double action as an express preemption provision and savings clause.

\footnotetext{
200. U.S. Dep't of Treasury v. Fabe, 508 U.S. 491, $493-94$ (1993).

201. 16 U.S.C. $\$ 1535$ (f) (2012).

202. E.g., H.J. Justin \& Sons, Inc. v. Brown, 519 F. Supp. 1383, 1387 (E.D. Cal. 1981), aff'd in part, rev'd in part on other grounds, 702 F.2d 758 (9th Cir. 1983), cert. denied, 464 U.S. 823 (1983).

203. Id
} 


\section{Section 6(f) as a Savings Clause: Non-Preemption by the ESA}

To perhaps state the obvious, and to underscore the importance of the Section 4 listing process, the ESA does not preempt any state or local regulation that does not affect a listed species. ${ }^{204}$ Thus, "with respect to unlisted species, section 6(f) leaves undisturbed the states' broad traditional regulatory authority." 205 Moreover, in the absence of evidence showing a continuing intent to preempt state law, states reacquire authority to regulate previously listed species-including trade in those species - after the USFWS or NMFS de-lists them. ${ }^{206}$

With respect to listed species, under Section 6(f), state laws can be more protective than the ESA without being preempted. Thus, for example, when the State of Florida imposed stricter penalties than the ESA for killing Florida panthers, an endangered species, the Florida Court of Appeals held that the ESA did not preempt state law, reasoning that:

[T]he Endangered Species Act and the regulations promulgated pursuant thereto do not specifically preempt state law in the conservation area. Only state laws that allow actions that the federal law precludes are prohibited. Consequently, the Florida legislature, which has the right to prohibit the killing of the Florida panther, has properly imposed stricter penalties which the Endangered Species Act allows states to do. ${ }^{207}$

Similarly, the ESA did not preempt New York's Wild Bird Law, which prohibited the sale of live wild birds unless they were born and raised in captivity, because dealers in New York had no federal license or permit to sell wild-caught ESA-listed species. ${ }^{208}$

In addition, under Section 6(f), state laws regarding ESA-listed species can also address different concerns than what the ESA addresses, so long as the resulting state law is not less restrictive than the ESA, does

204. Viva! Int'l Voice for Animals v. Adidas Promotional Retail Operations, Inc., 162 P.3d 569, 576 (Cal. 2007).

205. Id.

206. Id. at $580-82$.

207. State v. Billie, 497 So. 2d 889, 894 (Fla. Dist. Ct. App. 1986), rev. denied sub nom. Billie v. State, 506 So. 2d 1040 (Fla. 1987). For an argument that comprehensive state conservation plans should be allowed to "preempt" the ESA, see generally Malaika M. Eaton, Note, Of Salmon, Salamanders, and Lizards: Can State and Local Conservation Plans "Preempt" the Endangered Species Act?, 87 CORNELL L. REV. 185 (2001).

208. Cresenzi Bird Imps., Inc. v. New York, 658 F. Supp. 1441, 1443-46 (S.D.N.Y. 1987), aff'd per curiam, 831 F.2d 410 (2d Cir. 1987). 
not permit trade in the species that the ESA would prohibit, and does not prohibit trade in the species that the ESA would allow. For example, the town of Mount Pleasant, South Carolina, enacted an ordinance that "prohibit[ed] the possession of any "vicious or dangerous domesticated animal or any other animal . . . of wild, vicious or dangerous propensities.' The ordinance specifically makes it unlawful to possess wolves within the Town."209 Wolves are also an endangered species under the ESA, and people who wanted to keep wolves in their homes challenged the ordinance, claiming that the ESA preempted it. ${ }^{210}$ The South Carolina Supreme Court disagreed, finding the ordinance and the ESA largely inapposite:

The stated purpose of [the ESA] is to preserve the habitat of endangered species and provide a program for their conservation. The stated purpose of the local ordinance is to regulate the care and control of animals within the town limits to protect the safety, health and general welfare of the community. Under the [ESA] a permit can be obtained to possess endangered animals. The ordinance does not run contrary to the permitting of animals, but regulates the conditions under which certain animals can be kept in the town. Furthermore, the [ESA] provides that any state law respecting taking of endangered species may be more restrictive than federal exemptions or permits. ${ }^{211}$

\section{Section 6(f) Express Preemption}

Section 6(f)'s provisions regarding international and interstate trade in ESA-listed species essentially prohibit states and local governments from enacting any laws or regulations that differ from federal law. As a result, the U.S. Court of Appeals for the Ninth Circuit held that the ESA and regulations promulgated thereunder expressly preempted a California statute ${ }^{212}$ prohibiting trade of any elephant products because

209. Peoples Program for Endangered Species v. Sexton, 476 S.E.2d 477, 479 (S.C. 1996). "Exceptions are provided for private non-profit organizations established for educational purposes if: 1) the location conforms to the provisions of the Town's zoning code; 2) animals are kept in clean and sanitary conditions; 3) animals are maintained in quarters to prevent their escape; and 4) no person lives or resides within 200 feet of the animals' quarters." Id.

210. Id. at 480 .

211. Id. (citing 16 U.S.C. § 1535(f) (1985)).

212. Cal. Penal Code $\S 6530$ (a) (West 1983) ("It is unlawful to import into this state for commercial purposes, to possess with intent to sell, or to sell within the state, the dead body, or any part or product thereof, of any polar bear, leopard, ocelot, tiger, cheetah, jaguar, sable antelope, wolf (Canis lupus), zebra, whale, cobra, python, sea turtle, colobus monkey, kangaroo, vicuna, sea otter, free-roaming feral horse, dolphin or porpoise (Delphinidae), Spanish lynx, or elephant.”). 
the ESA regulations allowed for limited trade in African elephant products under special federal permits. ${ }^{213}$ An importer of African elephant ivory with a federal permit brought suit seeking declaratory relief that federal law preempted the state statute. ${ }^{214}$ In determining congressional intent, the Ninth Circuit noted that the ESA allows for state regulation of trade in species so long as the statute does not prohibit what the ESA and its implementing regulations permit. ${ }^{215}$ However, when the African elephant was added to the endangered species list, an accompanying regulation allowed for a special purpose permit "authorizing any activity otherwise prohibited." 216 California's outright ban on elephant products therefore prohibited what the ESA allowed and hence was expressly preempted. ${ }^{217}$

Courts have also repeatedly found that the ESA preempts state law protections for endangered and threatened species when the state law is less protective than the ESA. For example, the U.S. District Court for the District of Montana concluded that the ESA expressly preempted Montana's definition of a "taking," which did not include "habitat modifications," even though Montana was a party to a "full-authority comparative agreement" under the ESA. ${ }^{218}$ The court reasoned that:

[T] he clear language of $\S 6(\mathrm{f})$ of the ESA combined with the overwhelming priority Congress has given to the preservation of

213. 50 C.F.R. $§ 17.40$ (e) (1981) (allowing trade in African elephant products under special federal permits).

214. Man Hing Ivory \& Imports, Inc. v. Deukmejian, 702 F.2d 760, 761 (9th Cir. 1983).

215. Id. at 763 .

216. Id. at 764 (citing 50 C.F.R. $\S 17.40$ (e)(3) (1981) (“A special purpose permit may be issued in accordance with the provisions of $\S 17.32$ authorizing any activity otherwise prohibited with regard to such wildlife, upon submission of proof that such wildlife was already in the United States on June 11, 1978 or that such wildlife was imported into the United States in accordance with paragraph (e)(2) of this section.")).

217. Id. at 765 ("We affirm the district court's well-considered judgment that section 6(f) [sic] of the Endangered Species Act, together with 50 C.F.R. § 17.40(e), preempts California's statutory prohibition on trade in African elephant products by a trader who has secured all necessary federal permits.”). See also H.J. Justin \& Sons, Inc. v. Deukmejian, 702 F.2d 758, 759-60 (9th Cir. 1983) (holding that the ESA preempted California's prohibitions on trade in African elephant parts because federal law regulated such trade, but the ESA did not preempt California's prohibitions on trade in Indonesian pythons or Wallabee kangaroos, because those species were not listed under the ESA); Foulke Co. v. Brown, 463 F. Supp. 1142, 1144-45 (E.D. Cal. 1979) (holding that the ESA preempted California's prohibitions on trade in the American alligator when federal law allowed such trade). For a comprehensive discussion of ESA preemption and state laws banning commerce in certain species, see generally Tony Phillips, Note, Federal Preemption of State Commerce Bans Under the Endangered Species Act, 34 STAN. L. REV. 1323 (1982).

218. Swan View Coal., Inc. v. Turner, 824 F. Supp. 923, 938 (D. Mont. 1992) (internal quotations marks omitted). 
threatened and endangered species, [means] the court must conclude that the less restrictive takings provisions under Montana law are preempted by the ESA and that the definition of "take" under the ESA which includes "harm" and "significant habitat modification" is controlling in this case. ${ }^{219}$

Other courts have found, however, that Section 6(f) express preemption cannot be assessed if the federal government has not enacted a standard for species protection directly comparable to the state or local law at issue, such as lighting prohibitions for listed sea turtles. ${ }^{220}$

Following this logic, cases involving water management can invoke the ESA's express preemption provision, but generally only if the relevant state law relates directly to the protection of species and directly conflicts with an extant federal standard for protection. For example, in United States v. Glenn-Colusa Irrigation District, ${ }^{221}$ the U.S. District Court for the Eastern District of California confronted a situation in which the irrigation district's diversions of water from the Sacramento River had a well-documented history of causing harm to the ESA-listed Sacramento River winter-run chinook salmon as a result of salmon being killed or injured in the diversion's pumps. Starting in 1920, courts ordered the irrigation district to install fish screens to protect fish from being drawn into pumps. ${ }^{222}$ The district's failure to regularly maintain the screens resulted in periodic litigation, and the California Department of Fish and Game ended up installing the fish screens at issue in $1972 .{ }^{223}$ The main issue for the Eastern District of California was who was responsible for the taking of the listed salmon - the irrigation district because of its pumping, or California because of the screens that it installed. The court found the irrigation district liable because the screens presented no hazard in absence of the pumping. ${ }^{224}$

Along the way, however, the district court effectively found that federal definitions of causation and "take" had to govern the litigation,

219. Id.

220. See Loggerhead Turtle v. Cnty. Council of Volusia Cnty., Fla., 92 F. Supp. 2d 1296, 1308 n.19 (M.D. Fla. 2000) ("Plaintiffs do not argue that the ESA preempts the County's ordinance. While it is true that to the extent a state's regulation of 'taking' is less protective than the Act, it is preempted; see U.S. v. Glenn-Colusa Irr. Dist., 788 F. Supp. 1126 (E.D. Cal. 1992); such preemption is inapplicable here since the Secretary has not promulgated a lighting ordinance to which the County's can be compared.").

221. 788 F. Supp. 1126 (E.D. Cal. 1992).

222. Id. at 1129 .

223. Id.

224. Id. at 1133 . 
because "to the extent that California's law ... is less protective than the Endangered Species Act, it is preempted." 225 As a result, the district court rejected California's definition of proximate cause, which uses a substantial factor test, for assessing the "taking" of species, because it was less protective than the federal definition. ${ }^{226}$

\section{B. Implied Field Preemption by the ESA}

As noted, courts occasionally deem Congress to have "occupied the field" through federal regulation, excluding states from regulating on the same subject. However, because the ESA's express preemption provision allows states to regulate more stringently (i.e., to be more protective of species) than the ESA itself requires, courts have held that the ESA generally does not occupy the field of species protection. ${ }^{227}$ As a result, state water managers and state water law remain generally free to provide more protection (e.g., instream flows, habitat restoration) than the ESA might otherwise require.

On occasion, however, the ESA in combination with other federal statutes has been held to occupy the field with respect to particular species. For example, in In Defense of Animals v. Cleveland Metroparks $Z o o,{ }^{228}$ plaintiffs challenged the planned move of a male lowland gorilla from Ohio to the Bronx Zoo for mating purposes. The U.S. District Court for the Northern District of Ohio held that the plaintiffs' state law claims had to be dismissed because the ESA's preemption provisions, regulations implementing the ESA, and the federal Animal Welfare Act of $1970^{229}$ together wholly occupy the field of law regulating the transportation of ESA-listed lowland gorillas across state lines. ${ }^{230}$

In the context of water law, it is unlikely that any federal statute would generally preempt the field of state water law, especially given

225. Id. at 1134 .

226. Id.

227. See H.J. Justin \& Sons, Inc. v. Brown, 519 F. Supp. 1383, 1389 (E.D. Cal. 1981), aff'd in part, rev'd in part on other grounds, 702 F.2d 758 (9th Cir. 1983), cert. denied, 464 U.S. 823 (1983) (" $[\mathrm{T}]$ his Court must find that Congress did not intend to preempt California Penal Code ss 653o and 653 r, except to the extent that those sections prohibit what is authorized by a permit or exemption issued pursuant to the Act or its regulations.").

228. 785 F. Supp. 100 (N.D. Ohio 1991).

229. 7 U.S.C. $\$ \S 2131-2159$ (2012).

230. In Defense of Animals, 785 F. Supp. at 102. Compare with Viva! Int'l Voice for Animals v. Adidas Promotional Retail Operations, Inc., 162 P.3d 569, 577 (Cal. 2007) (holding that the ESA does not occupy the field with respect to the import and sale of kangaroos). 
Congress's traditional and repeated solicitude toward state water law. ${ }^{231}$ Nevertheless, with regard to specific and heavily federally managed river systems, the combination of the ESA and federal water management statutes and federal water management plans could effectively preempt state efforts on the same river. As one illustrative non-water rights example, the U.S. Court of Appeals for the Eighth Circuit has held that the U.S. Army Corps of Engineers' management of the Missouri River, which is dictated by the federal Flood Control Act and to a lesser extent by the federal Clean Water Act, is exempt from the requirements that state water quality standards would otherwise impose on the system. ${ }^{232}$

\section{The ESA and Conflict Preemption of State Water Law}

Conflict preemption, as noted above, is the minimum constitutional import of the Supremacy Clause. Thus, to the extent that state law actually conflicts with federal law, either generally or in a specific application, the state law will be preempted.

Distinguishing ESA conflict preemption from ESA express preemption can be difficult, because Section 6(f) expressly preempts state laws in conflict with the ESA. As a result, although the line between express and conflict preemption can be thin, courts usually apply conflict preemption principles when assessing the validity of state and local government laws that do not directly regulate or affect ESAlisted species, concluding that the ESA can preempt conflicting state laws as applied even when it does not expressly preempt those state laws on their face. ${ }^{233}$

For example, when fishing regulations in Massachusetts that governed non-listed species allowed fishers to set lobster traps in ways that caused "takes" of listed and endangered Northern right whales, the U.S. Court of Appeals for the First Circuit held that the ESA preempted

231. Robin Kundis Craig, Adapting Water Federalism to Climate Change Impacts: Energy Policy, Food Security, and the Allocation of Water Resources, 5 ENVTL. \& ENERGY L. \& POL'Y J. 183, 188-89, 194-97 (2010); see generally Reed D. Benson, Deflating the Deference Myth: National Interests vs. State Authority under Federal Laws Affecting Water Use, 2006 UTAH L. REV. 241 (2006).

232. In re Operation of Mo. River Sys. Litig., 418 F.3d 915, 917-20 (8th Cir. 2005).

233. Strahan v. Coxe, 127 F.3d 155, 168 (1st Cir. 1997) ("By including the states in the group of actors subject to the Act's prohibitions, Congress implicitly intended to preempt any action of a state inconsistent with and in violation of the ESA."); Aransas Project v. Shaw, 930 F. Supp. 2d 716, 783 (S.D. Tex. 2013) ("State agency regulations, to the extent they conflict with the ESA, are preempted, pursuant to the Supremacy Clause." (citation omitted)). 
the state licensing rules. ${ }^{234}$ By creating a situation where lines and fishing gear would be placed in the whales' paths, promoting entanglements and harm to (or even deaths of) those whales, the Massachusetts fishing licenses posed an obstacle to the ESA's objective of protecting the Northern right whale from harm. Specifically, the First Circuit concluded that:

By including the states in the group of actors subject to the Act's prohibitions, Congress implicitly intended to preempt any action of a state inconsistent with and in violation of the ESA. We agree with the district court that the Commonwealth's regulation of commercial fishing likely results in a taking in violation of the far-reaching prohibitions of the ESA. The district court properly concluded that the scheme as it presently operates cannot continue insofar as its operation is inconsistent with the intent of the ESA. ${ }^{235}$

Similarly, in 1998, California voters passed an initiative that made it illegal (and criminal) to use certain animal traps and poisons, including steel-jawed leghold traps. ${ }^{236}$ Federal agencies, however, used such traps to protect threatened and endangered species. ${ }^{237}$ The Ninth Circuit held that the ESA preempted California's complete ban on the use of these traps because the ban prohibited any person, including federal agencies, from using traps and poisons for any reason. ${ }^{238}$ Because there was no exception for endangered species, the California initiative precluded federal agencies from protecting endangered species under the ESA as the ESA requires, creating a conflict between federal and state law. ${ }^{239}$

Conflict preemption is thus the most likely mode of preemption analysis that a court will use when the state or local regulation at issue has nothing directly to do with ESA-listed species - or even species regulation at all. For example, when the City of South San Francisco amended a residential land use development plan for San Bruno Mountain in order to comply with the ESA, the California Court of

\footnotetext{
234. Strahan, 127 F.3d at 168.

235. Id.

236. CAL. FISH \& GAME CODE $\S \S 3003.1-.2,12005.5$ (West 1998).

237. Nat'l Audubon Soc'y, Inc. v. Davis, 307 F.3d 835, 844, opinion amended on denial of reh'g, 312 F.3d 416 (9th Cir. 2002).

238. Id. at 852,859 .

239. See id. at 853 ("We do not read [16 U.S.C. § 1535(f)] to carve out an exception to the ESA that would allow the state to conserve wildlife that is not endangered ...."). See also Pac. Nw. Venison Producers v. Smitch, No. C92-1076WD, 1992 WL 613294, at *7 (W.D. Wash. Sept. 2, 1992) aff'd in part, 20 F.3d 1008 (9th Cir. 1994) (holding that the ESA expressly preempted a Washington state law that would have prohibited propagation of the ESA-listed sika deer).
} 
Appeals held that "[f]orcing a developer to submit an amendment to the referendum process . . . conflicts with overriding federal authority." 240 Similarly, the Idaho Supreme Court concluded that the ESA preempted a Boundary County ordinance requiring that the county concur before adjustments to uses of federal lands could occur. ${ }^{241}$ According to the court, the county's purported "veto authority":

[I]s contrary to the provisions of the Endangered Species Act of 1973, 16 U.S.C. §§ 1531-1543 (1985 \& Supp. 1995), which authorizes the Secretary of the Interior, the Secretary of Commerce, and the Secretary of Agriculture to acquire land to carry out the purposes of the Act. 16 U.S.C. § 1534. It is also contrary to the portion of the Endangered Species Act which requires the Secretary of the Interior and the Secretary of Commerce to develop and implement recovery plans for endangered species. 16 U.S.C. § 1533(f). This veto power stands as an obstacle to the accomplishment of the full purposes and objectives Congress evidenced in these federal laws. ${ }^{242}$

As such, conflict preemption is likely to be the most important form of ESA preemption analysis in the water resource and water rights contexts. Unlike state fish and game laws, state laws regarding water rights and water management generally do not directly regulate species; moreover, to the extent that these laws address species or biodiversity, they generally act to preserve aquatic species. As a result, the ESA's express preemption provision is unlikely to be relevant. Nevertheless, because implementation of water rights and water management measures can directly affect aquatic species' habitat and food supplies, they can become obstacles to the protection and recovery of particular listed species.

The Southern District of Texas's March 2013 decision in Aransas Project $v$. Shaw ${ }^{243}$ exemplifies the potential importance of conflict preemption when water management interferes with ESA-listed species. Indeed, as important as-although far less detailed than - the court's findings on Section 9 causation was its unflinching and repeated conclusion that the ESA trumped state water law in the face of conflict. Thus, for example, when the defendants suggested that Texas's new (and arguably improved) water legislation, S.B.3, displaced the need for this case, the court concluded that:

\footnotetext{
240. W. W. Dean \& Assocs. v. City of South S.F., 190 Cal. App. 3d 1368, 1379 (1987).

241. Boundary Backpackers v. Boundary Cnty., 913 P.2d 1141, 1147-48 (Idaho 1996).

242. Id. at 1147 .

243. 930 F. Supp. 2d 716 (S.D. Tex. 2013).
} 
[T]o suggest that S.B.3 can protect the whooping cranes, when by its own admission, it specifically excludes the cranes' habitat in times of water emergencies, is to argue that state law preempts federal law. This topsy-turvy view of federalism and the Constitution's Supremacy Clause has no basis in the existing constitutional scheme. ${ }^{24}$

Similarly:

The fact that those diversions [from the Guadalupe and San Antonio Rivers] were "lawful water diversions under preexisting permits" is irrelevant in the context of this case because, as previously discussed, the ESA preempts state law to the extent it authorizes activities that cause a prohibited take of a listed species. ${ }^{245}$

Again, as a finding of law, "The Supremacy Clause of the U.S. Constitution, U.S. Const. art. VI, cl. 2, ensures that Section 9 of the ESA preempts contrary state regulations and other state laws."246

Thus, despite the fact that the Texas Commission on Environmental Quality (TCEQ) issued water rights largely independently of species considerations, the cumulative exercise of the water rights it issued could affect ESA-listed species. Moreover, in the face of the court's finding that there was an actual conflict between the implementation of Texas water law (issuance of prior appropriation rights and refusal to curtail those rights in the face of drought) and the ESA (the whooping cranes' need for viable habitat and food supplies), federal conflict preemption dictated the outcome of the case. Aransas Project should be considered a harbinger of outcomes for the many non-federally mediated ESA-water rights conflicts to come.

\section{CONCLUSION}

Given the U.S. Constitution's Supremacy Clause and the established ability of state water law to conflict with federal law requirements to protect ESA-listed species, the ESA's continued preemption of state water rights is inevitable. Just as inevitable, as the litigation histories of the Klamath Basin and Edwards Aquifer indicate, are follow-on lawsuits arguing that the federal government has taken vested property rights without compensation, in violation of the Fifth Amendment to the U.S. Constitution.

\footnotetext{
244. Id. at 737.

245. Id. at 745 .

246. Id. at 783 .
} 
It is tempting, from both the property rights and environmentalist sides of the debate, to portray this litigious seesaw between the Supremacy Clause's constitutional mandate and the Fifth Amendment's constitutional protection of property rights as a legal tragedy in need of reform. However, it is also important to remember two things about conflicts between state water law and the ESA: (1) the Fifth Amendment problem arises only in states that characterize private water rights as absolute property rights, which is generally true only in the Mountain West and non-coastal southwest states; and (2) even in those states, a tunnel-vision focus on ESA-water conflicts obscures the larger problems surrounding water management. ESA-listed water-dependent species are the proverbial canaries in these aquatic mines, warning that the relevant states have larger water resource problems facing them.

To expand briefly on point (1), few states view water rights as absolute property rights. Over half the states (mostly in the East) base their surface water rights on common law riparianism, under which water rights have always been subject to the doctrine of reasonable use and the evolving needs of other water users, rendering all water rights contextual and subject to change. "Regulated riparian" states - eastern states like Florida that have adopted permit programs for water rights - maintain this common law flexibility through time limits on permits and other mechanisms. Similarly, the groundwater doctrines employed in the majority of states - reasonable use and correlative rights-also define water rights to be flexible and contextual.

Even among the minority of states that use prior appropriation for surface water or groundwater rights (or the rule of capture for groundwater), many have declined to figure water rights as absolute property. Most famously, states like California and Hawaii subject water rights to both a strong public trust doctrine and a plethora of permit conditions, both of which allow these states to adjust water rights as circumstances (such as species' needs) demand.

Water rights in most states, in other words, can (and under the Supremacy Clause, must) accommodate the ESA when there is an absolute conflict between human water use and the mandated requirements for listed species, and no Fifth Amendment taking should thus result from implementing the ESA's protections. Even in those prior appropriation states that declare water rights to be absolute property rights, however, inherent limitations on water rights do exist: the rule of priority, which limits more junior rights by the prior demands of more senior rights; the doctrines of abandonment and forfeiture, which eliminate or reduce vested water rights for non-use; and the common law 
doctrine of public necessity, which allows governments to destroy private property without compensation during emergencies. Thus, even in these states it is not always clear that conflict preemption by the ESA necessarily takes private water rights in violation of the Fifth Amendment, particularly if the water rights holders have not bothered to apply for a Section 10 Incidental Take Permit, the issuance of which (and its accompanying Habitat Conservation Plan) would legally accommodate both the water rights and the ESA-listed species. Notably, the Southern District of Texas in Aransas Project chose to require the TCEQ to apply for a Section 10 permit as its prescribed remedy for the ESA-water rights conflict.

Nevertheless, too intense a focus on ESA preemption in water resource management is almost certainly counterproductive. Notably, most litigated ESA-water rights conflicts to date have arisen in the context of drought. The identification of "drought" allows the immediate resolutions of the ESA litigation to be conceived of as temporary fixes that will disappear when everything "goes back to normal," undermining the ESA's arguably more important role as a more general alarm signal for particular aquatic systems. Nevertheless, as human populations grow and shift, climate change increasingly impacts water resources and their related ecosystems, aquifers run dry, the increasing quantification and exercise of tribal reserved water rights subordinate long-existing appropriative rights, and other factors increase the stresses to particular water systems, more far-reaching accommodations among water users (including aquatic ecosystems) will be needed than ESA preemption can provide. For the future, therefore, ESA preemption of state water law is probably much better viewed not as a quirk of particularly severe drought years but rather as a signal that particular water systems need substantially revised management-revisions that go far beyond either the ESA or state water law. 